Rhode Island College

Digital Commons @ RIC

\title{
Interventions to Decrease Mortality Among Patients with Acute Respiratory Distress Syndrome
}

Emily Cohn

Follow this and additional works at: https://digitalcommons.ric.edu/etd

Part of the Nursing Commons

\section{Recommended Citation}

Cohn, Emily, "Interventions to Decrease Mortality Among Patients with Acute Respiratory Distress Syndrome" (2021). Master's Theses, Dissertations, Graduate Research and Major Papers Overview. 392.

https://digitalcommons.ric.edu/etd/392

This Major Paper is brought to you for free and open access by the Master's Theses, Dissertations, Graduate Research and Major Papers at Digital Commons @ RIC. It has been accepted for inclusion in Master's Theses, Dissertations, Graduate Research and Major Papers Overview by an authorized administrator of Digital Commons @ RIC. For more information, please contact digitalcommons@ric.edu. 


\title{
INTERVENTIONS TO DECREASE MORTALITY AMONG PATIENTS WITH ACUTE RESPIRATORY DISTRESS SYNDROME
}

by

\author{
Emily Cohn
}

A Major Paper Submitted in Partial Fulfillment

of the Requirements for the Degree of

Master of Science in Nursing

in

The School of Nursing

Rhode Island College 


\begin{abstract}
Acute respiratory distress syndrome (ARDS) is a severe complication which affects thousands of patients every year and is associated with high mortality rates and increased healthcare costs. A systematic review was conducted to determine the efficacy of various interventions used to decrease the staggering mortality rate of ARDS. The interventions studied were extracorporeal membrane oxygenation (ECMO), prone positioning, and neuromuscular blockade. Data bases searched were Google Scholar, PubMed, Cochrane library, and the CINAHL databases to find relevant research articles and a literature review conducted. A total of 21 articles were considered and screened for inclusion/exclusion criteria, ultimately yielding five articles included in this systematic review. To guide this major project, the Reporting Items for Systematic Reviews and Meta-Analyses (PRISMA) checklist and flow diagram were utilized. To further assess the quality of reach study, the Critical Appraisal Skills Programme (CASP) checklist was used. A cross study analysis was performed to compare identified outcomes. This systematic review determined one study to be underpowered, one study demonstrated a decrease in mortality in the intervention group but was not statistically significant, and two studies were stopped for futility. One study was adequately powered and displayed a significant decrease in mortality rate. The results of this systematic review indicates further research is needed on the efficacy of interventions to decrease ARDS-related mortality and guide advanced practice nurse decision-making.
\end{abstract}




\section{Table of Content}

Background/Statement of the Problem ................................................................ 1

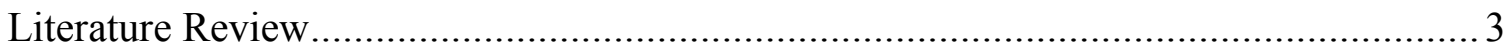

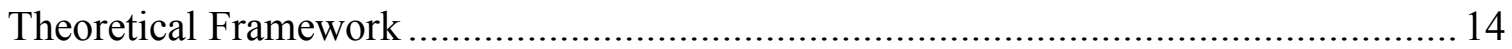

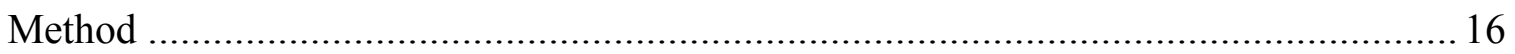

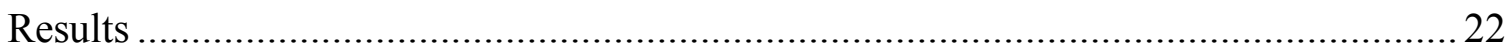

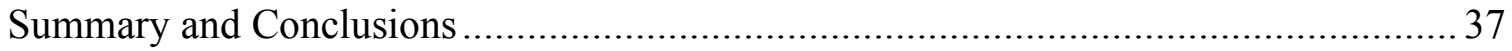

Recommendations and Implications for Advanced Nursing Practice ........................... 42

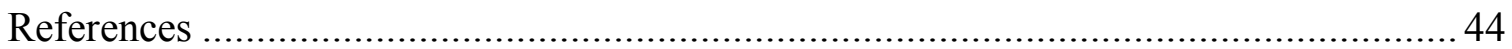

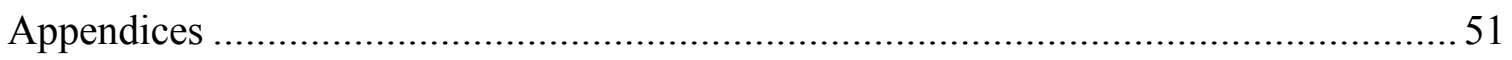


Interventions to Decrease Mortality Among Patients with Acute Respiratory Distress Syndrome

\section{Background/Statement of the Problem}

Acute Respiratory Distress Syndrome (ARDS) is an acute, life-threatening condition requiring intensive care unit (ICU) level of care and technology. ARDS reflects poor oxygenation and non-compliant lungs due to capillary endothelial injury and diffuse alveolar damage (Patel et al., 2019). An international study involving 29,144 patients revealed $10 \%$ of individuals admitted to the ICU and $23 \%$ of patients who were mechanically ventilated were diagnosed with ARDS, with a morality rate as high as $46 \%$ (Thompson et al., 2017). Other recent research has reported mortality rate of ARDS at approximately $40-50 \%$ with up to 150,000 cases being diagnosed in the United States annually (El-Haddad et al., 2017). These authors further describe factors that may impact the mortality outcome prediction for this population such as the diagnosis of cancer, body mass index, age, a diagnosis of diabetes mellitus, and gender. Thompson et al. (2017) states that ARDS is likely unreported in low-income countries and may be underrecognized in high-income countries. Therefore, the data available indicates the problem may be larger than can be quantified.

Etiologies responsible for ARDS are vast with no single therapy or medication proven to combat the high mortality rates. To compound the difficulties associated with ARDS, diagnosis relies on chest radiologic images and clinical presentation only; no designated biomarkers have yet been validated (Thompson et al., 2017). These authors note that genetic susceptibility is highly suspected, however, and that patients with clinical risk factors, such as sepsis, pneumonia, or trauma, do not necessarily develop 
ARDS. Some symptoms that manifest consist of cyanosis, diffuse crackles, dyspnea, tachycardia, tachypnea and diaphoresis (Norris, 2019).

Treatment of ARDS patients, including neuromuscular blockade, low volume, low pressure ventilator settings, and cautious fluid management have been extensively studied and explored. This literature review will survey the current information regarding three common interventions chosen to support these patients. Prone therapy is utilized to maximize the use of viable lung tissue with the use of safe mechanical ventilator settings without causing further lung injury. Another option is extracorporeal membrane oxygenation (ECMO) therapy, which requires a more invasive, extravascular cannulation system designed to improve oxygenation and ventilation while reducing lung injury induced by mechanical ventilation. Neuromuscular blockade is an alternative intervention as well, utilizing a prescribed infusion of a sedative to decrease the accumulation of alveolar fluid, work of breathing, and dyssynchrony with the ventilator. Benefits, risks, limitations, and notably high mortality rates occur with each intervention leaving a large area of debate regarding which intervention benefits this population. Therefore, the purpose of this study is to compare best evidence regarding the treatment options, prone therapy, ECMO therapy, and neuromuscular blockade in decreasing mortality rates for adult patients with ARDS. The next section will discuss the review of the literature. 


\section{Literature Review}

\section{Pathophysiology and Definition}

ARDS is the most severe form of acute lung injury (ALI), and defining signs and symptoms of capillary endothelial injury and diffuse alveolar damage are thus more pronounced (Norris, 2019). Lung tissue alterations increase the permeability of the alveoli sacs which allows for other fluid and substances from the capillary, such as blood cells and proteins to enter into the area originally designated for gas exchange only. The resulting abnormalities in surfactant production cause alveolar collapse and further compromise gas exchange. This alteration in permeability allows for accumulation of impervious fluids and diminishes adequate surface area to optimize the intake of oxygen $\left(\mathrm{O}_{2}\right)$ and release of carbon dioxide $\left(\mathrm{CO}_{2}\right)$. Once progression ensues, the lungs also become less elastic, stiff, and ultimately more difficult to inflate. With the alignment of these detrimental factors, ventilation (V) and perfusion (Q) are no longer adequate and reciprocal and is noted as a VQ mismatch. Patients with ARDS display intrapulmonary shunting of blood, diminished gas exchange, and refractory hypoxemia despite receiving the highest levels of supplemental $\mathrm{O}_{2}$ (Norris, 2019).

Additionally, in the setting of ARDS, alveolar macrophages act as defense against pathogenic microorganisms and release strong proinflammatory mediators, such as cytokines, which characteristically build up and contribute to further tissue damage (Carlucci et al., 2014). Lastly, dead space is often measured in studies regarding ARDS. Dead space accounts for the air trapped in spaces when there is decreased diffusion, which is normal; however, in ARDS, dead space is more extensive, leading to the diminished oxygenation and increased mortality risk (Kallet et al., 2017). 
Diagnosing severe ARDS is identified by mechanical ventilator settings and is defined as a $\mathrm{PaO}_{2}: \mathrm{FiO}_{2}$ ratio of $<150 \mathrm{~mm} \mathrm{Hg}$, with an $\mathrm{FiO}_{2}$ of $\geq 0.6$, a PEEP of $\geq 5 \mathrm{~cm}$ of water, and a tidal volume of about $6 \mathrm{ml}$ per kilogram of predicted body weight, which is consistent with the American-European Consensus Conference criteria (Guérin, et al., 2013). $\mathrm{PaO} 2$ represents partial pressure of arterial oxygen, which is normally between 75 $100 \mathrm{~mm} \mathrm{Hg}$ (Ferri 2019 p. 146). The normal percentage of the FiO2 in the air we breathe is approximately $21 \%$ while ventilated patients are receive $21 \%$ to $100 \%$, depending on patient-specific requirements. Positive end expiratory pressure (PEEP) is additionally used to keep alveoli open and provide a prescribed amount of pressure to force oxygenated air into the lung tissue, thereby increasing alveolar recruitment and preventing collapse (Gattinoni et al., 2017). Of note, the benefit of alveolar recruitment is that once the alveoli are properly inflated, there is an increase in surface area in the lungs which allows for improved gas exchange (Marino, 2014). Elevated settings of PEEP and tidal volume are often pushed to their limits to gain sufficient oxygenation in the noncompliant lung; however, such elevations place the patient at risk for suffering lung injury. Prone therapy, ECMO, and neuromuscular blockade are used as a solo therapy or used together to minimize these mechanical ventilation associated risks.

\section{Etiologies}

Several physiologic events and illnesses can lead to the development of ARDS, making the prediction of its occurrence difficult to identify at the early stages, or sometimes at all. Direct causes, such as inhalation injuries gained from exposure to fire related smoke or aspiration, may be responsible for initiating the devastating respiratory disorder. Anything that causes inflammation within the patient also poses a risk for 
ARDS as well, including sepsis, pancreatitis, influenza virus, pneumonia, drug or toxin reaction, and trauma (Norris 2019). No matter which process initiates severe ARDS in a patient, it results in excessive ventilation relative to pulmonary capillary blood flow, which increases dead space ventilation, and less gas exchange with each breath (Marino, 2014). One statistical analysis concluded that the fraction of pulmonary dead space serves as an indicator of mortality risk and further, that pulmonary dead space fraction varies from etiology to etiology (Kallet et al., 2017).

\section{Prone Therapy}

For decades, prone therapy has been utilized to facilitate improved outcomes in the survival of ARDS patients. Quite literally, the patient is flipped to a prone position in bed to optimize oxygenation to a greater portion of lung tissue in the ICU setting. Regarding lung recruitment, Kallet et al. (2015) notes that the prone position and proper PEEP have an additive effect which lessen the chances for ventilator associated lung damage. The authors emphasize the importance of utilizing the greater portion of lung tissue, since approximately $50 \%$ of lung tissue is oriented to the dorsal plane of an adult, whereas only $20 \%$ is oriented to the ventral portion. With increased surface area of the alveoli employed, more fluid reabsorption is possible, lessening the notable pulmonary edema which is excess fluid accumulation in the lungs inhibiting optimal oxygenation (Norris, 2019). Prone maneuvering also encourages a more homogenous distribution of trans-pulmonary pressure within each alveolus (Kallet, 2015).

Attempts have been made to capitalize on the benefits from position changes in patients with ARDS. Robak et al. (2011) directed a prospective randomized control study 
of 20 adult patients with ARDS and the use of prone positioning to improve $\mathrm{PaO}_{2} / \mathrm{FiO}_{2}$ ratio. When compared to supine positioning, a positive response in the ratio was detected in $14(70 \%)$ of patients in the prone position, whereas 17 patients $(85 \%)$ had responded to prone plus the upright positioning. Though this study reported improved oxygenation, some study limitations diminish the integrity of the findings. The lack of a more robust sample discredited the findings, since only 20 patients were included in the study. The choice to alternate patient positions from supine, to prone, to upright in two- to six-hour increments also weakened the study. In addition, mortality rate was not specifically measured in this study.

Additional research of adult patients with ARDS investigated the use of prone therapy in those sharing the same etiology. Mutkule et al. (2016) examined six individuals with ARDS who were diagnosed with $\mathrm{H} 1 \mathrm{~N} 1$ and received prone therapy treatment to decrease mortality rates. In the beginning of the study, 43 patients were swabbed and positive for $\mathrm{H} 1 \mathrm{~N} 1$, however only 17 required mechanical ventilation. Of the 17 patients, 11 improved with typical ventilation settings after 12 hours. Six of the remaining patients continued to demonstrate a low $\mathrm{PaO}_{2} / \mathrm{FiO}_{2}$ ratio and were subsequently proned for 16 hours followed by 8 hours in the supine position. Until the patient maintained a $\mathrm{PaO}_{2} / \mathrm{FiO}_{2}$ ratio greater than 150 , the 16 -hour prone/8-hour supine pattern continued. The authors conclude the average ICU length of stay was 11.16 days and that there were no deaths at day 28 and 90. Ultimately, the study yielded results which ultimately proved to be inadequate. Etiology of ARDS is far too varied to represent a sample which only included those simultaneously diagnosed with H1N1 
virus. Outcomes will likely vary in ARDS patients depending on etiology (Kallet et al., 2017) and thus cannot be included in the systematic review.

Another aspect of ARDS is considered by Kallet (2015) who writes that recent evidence of $\mathrm{PaO}_{2}$ and $\mathrm{PaCO}_{2}$ (partial pressure of arterial carbon dioxide) responders in prone therapy reflect the extent and distribution of lung injury, rendering the impact of alveolar ventilation improvement using prone positioning less consistent. Further analysis of prone therapy and its benefits and setbacks are required, and lower mortality rates in patients with ARDS are required.

\section{Manual vs. Automatic Prone Therapy}

Instead of manual proning, some institutions have utilized automatic prone therapy with a specialty bed which maintains the patient between two mattresses and flips them from supine to prone and back to supine at prescribed intervals. This specialty mattress is not one undivided surface, but several secured, cushioned pieces which are able to be unlatched individually for nursing assessments. Additionally, while prone, the bed slowly tips the patient to the right and the left at pre-programmed angles. Locating studies to determine the efficacy of this intervention proved to be difficult and sparse.

A retrospective, descriptive-comparative approach was constructed in recent years to determine the effects of automatic versus manual prone therapy on patient outcomes. Morata et al. (2017) analyzed 24 months of data and a total of 37 adult subjects who met the ARDS criteria. Of these patients, 16 received manual therapy and 21 received automatic therapy. The authors analyzed variables such as demographic information, hospital length of stay (LOS), ICU LOS, discharge disposition, and complications. 
Ultimately, those who were manually proned had a reduction in ICU LOS and hospital LOS, were discharged to home in greater numbers, and had fewer complications. The complications noted were pressure injuries, which were the most common, and tube and line dislodgement. Automatic prone therapy did not prove to be more useful than manual proning in this study, meaning that utilizing the prone therapy mattress or a team of staff to prone the patient will produce similar outcomes. Larger, randomized control trials are warranted to create more meaningful data and to produce more conclusive results.

\section{ECMO therapy}

Extracorporeal Membrane Oxygenation (ECMO) therapy provides respiratory and cardiac support, aiding in gas exchange and perfusion. The first documented use of ECMO in rescue therapy for ARDS dates back to 1972 according to Parekh et al (2018). This therapy incorporates an assembly of machines, such as a pump, a control panel, a blender and an oxygenator, to pump blood in and out of the patient. This is done by way of a single or double lumen venous cannulation system or a venous-arterial system with three cannulations. In patients with severe ARDS, the two-fold benefit from ECMO is to first confirm satisfactory oxygenation and ventilation, and second, to reduce ventilatorinduced lung injury by facilitating low-volume, low-pressure ventilation. (Parekh et al., 2018).

A retrospective case-control study was conducted to compare outcomes of adult patients diagnosed with ARDS who received ECMO for treatment and those who did not (Tsai et al., 2015). The choice to treat or not treat with ECMO was based on the Acute Physiologic and Chronic Health Evaluation II (APACHE II) score and age. The 
researchers originally sampled 216 patients, however, after the APACHE II screening, the author's sampled 45 ECMO and 45 non-ECMO ARDS patients. There was no substantial difference in the $\mathrm{PaO}_{2} / \mathrm{FiO}_{2}$ ratio in either group. The ECMO group did, however, exhibit a lower mortality rate than its counter group (55\% vs. $65.1 \%$, respectively). Although improvements in oxygenation and survival rates were illustrated in this case, the sample size was relatively small (90 patients) and it took place in one healthcare facility only.

ECMO therapy was endorsed as treatment in a case-control study which involved 15 cases between 2010-2016, totaling 52 adult patients with ARDS (Muñoz, et al., 2017). This research identified increased survival in ARDS patients when treated with ECMO, displaying a mortality rate of $47 \%$ vs. non-ECMO $77 \%$. However, longer inpatient stays and complications due to user error/insufficient training were demonstrated. Four patients died due to complications related to ECMO therapy. Again, though ECMO provided a better chance of decreasing mortality, the odds of surviving are still low.

\section{Neuromuscular Blockade}

Inducing paralysis via pharmacologic measures may aid in the reduction of mortality rates among individuals with ARDS. In the setting of appropriate neuromuscular blockade delivery, one expects increased compliance between the ventilator and the patient, decreased work of breathing, and less fluid accumulation in the alveoli. Ultimately, this should result in a reduction of ventilated days, less time spent in the ICU, less barotrauma, and benefit overall mortality rates. Various paralytics can be chosen to attain these goals. Challenges surrounding this method include selection of the 
correct paralytic, correct dose, accurate monitoring, such as with the train of four (TOF), and risk of residual neuromuscular weakness (Merkel et al., 2019). The TOF is a standard method in monitoring drug induced paralysis by applying two electrodes to the skin at the ulnar nerve, delivering four low frequency electrical impulses, then observing for a twitch, demonstrated as a brief adduction of the thumb (Marino, 2014). This establishes a baseline response for the nurse to subsequently titrate the drug to achieve paralysis safelty.

Duration of neuromuscular blockade therapy may impact outcomes in ARDS patients as well. A retrospective review was conducted on adults with ARDS in a surgical intensive care unit to establish whether cisatricurium infusion under 48 hours (SHORT) or for longer periods of time (LONG) affected mortality rate. Beyond the 48-hour window of time, paralytic administration has not been evaluated due to increased concern for severe complications, such as neuromuscular dysfunction, weakness, increase in ICU days, and greater time spent on a ventilator. Out of the selected 73 patients, 32 (44\%) were in the SHORT group and $41(56 \%)$ were entered into the LONG group. The demographics of both groups were comparable except that the SHORT study contained slightly older patients. Overall, 60\% mortality was observed, and similar occurrences of deep vein thrombosis and pneumonia were measured in each study group (Barmparas et al., 2018).

Limitations of this study were significant, however, in that the sample size was small, the initiation and discontinuation of cisatricurium was not based on a protocol, but rather practice of the intensivists employed, and information was collected from a single 
institution. The researchers concluded that longer duration of neuromuscular blockade in patients with ARDS may be necessary but higher quality studies are required.

In a single-center, retrospective cohort study, Merkel et al. (2019) set out to determine proper administration of cisatricurium IV infusion in ARDS patients and identify clinical elements that affect dosing. The data was obtained on 120 newly intubated adults who had received cisatricurium. Of note, patients with ARDS of a less severe category with a $\mathrm{PaO}_{2} / \mathrm{FiO}_{2}$ of less than $301 \mathrm{mmHg}$ were employed for this research. To ensure an adequate level of paralysis, TOF parameters were utilized to capture patients which had documented $1 / 4$ or $2 / 4$ twitches. Institutional policies recommended initial infusion rate of cisatricurium at $0.5-10 \mu \mathrm{g} / \mathrm{kg} / \mathrm{min}$ and to increase the drug by $25 \%$ per hour to obtain the prescribed number of twitches. A dose was considered "stable" if two consecutive, desired TOF readings occurred on the same site after at least three hours of infusion initiation. Thirty-nine patients met the stable dose criteria and were used in the final analysis.

Ultimately, this small study determined that in order to achieve a TOF of $1 / 4$ or $2 / 4$ the median dose of cisatricurium was $2 \mu \mathrm{g} / \mathrm{kg} / \mathrm{min}$ and that dosing requirements are less in those with acute kidney injury (AKI). Unfortunately, surveys obtained displayed $50-60 \%$ of nurses measuring TOF are inconsistent, rendering the results less useful. Additionally, a mortality rate of $56 \%$ was recorded, which is higher than the national average of ARDS mortality and is likely due to the large percentage of immunosuppressed patients studied. Due to these variables and the small sample size, this study is clinically insignificant. 


\section{Combined Therapies}

Management strategies for patients with ARDS largely surround the avoidance of the development of ventilator-associated lung injury. Some of the selected studies had used ECMO, neuromuscular blockade and prone therapy together. The lung-protective methods of low volume, low pressure ventilator settings can be complicated by hypercapnia and subsequent respiratory acidosis (Parekh et al., 2018). ECMO can mitigate this issue by removing carbon dioxide from the blood. One reviewer writes that proning the patient may be beneficial when combined with ECMO if it is safe and feasible, however, prone positioning should be considered without ECMO first if low volume, low pressure ventilator settings can be achieved (Parekh et al., 2018).

Prone position therapy and ECMO were combined in a retrospective, singlecenter analysis that focused on 12 patients diagnosed with ARDS. Patients had to be ventilated for under 60 days before ECMO and prone positioning could be initiated. Kipping et al. (2013) hypothesized that the facilitated alveolar recruitment from prone positioning shared with the rest which ECMO provides the lungs would yield improvement in oxygenation and reduce risk of acute lung injury. In the conclusion, the researchers note these two therapies combined may improve oxygenation, however, the study is small and the ECMO equipment studied is somewhat out of date. An interesting and important feature extracted in this study is that ECMO and prone therapy were able to occur simultaneously in all 12 patients without complications such as loss or dislocation of intravascular catheters or endotracheal tubes (Kipping et al., 2013). These findings offer encouragement for larger studies in the future. 
The combination of prone positioning and ECMO therapy were also observed in a prospective study of 15 patients with severe ARDS (Guervilly et al., 2014). Adult patients were proned if he/she demonstrated a $\mathrm{PaO}_{2} / \mathrm{FiO}_{2}$ was less than $70 \mathrm{mmHg}$, plateau pressures of greater than $32 \mathrm{cmH}_{2}$, or were unable to wean from ECMO after 10 days of support. Participants were also heavily sedated and paralyzed with ciastracurium. Of the 15 patients, two had proned for two sessions and nine had proned for one session. The median amount of time spent in the prone position was 12 hours. In conclusion, oxygenation was greatly improved by prone positioning and may help to wean a patient off ECMO. Limitations exist, however, such as the small sample size and delayed use of proning. Of note, complications such as decannulation or accidental extubation did not occur as a result of prone maneuvering.

Information and studies may be lacking overall to delve further into the superiority of manual versus automatic proning. Otherwise, variables are highlighted in prone therapy, neuromuscular blockade and ECMO therapy in the form of hospital LOS, ICU LOS, discharge disposition, and complications. Combatting ARDS mortality rate most effectively, however, is not yet determined based on these studies. Once comparison of appropriate RCT's is underway, the researcher aims to display conclusive evidence to support one therapy over the other. 


\section{Theoretical Framework}

The utilization of a theory or concept framework in research is imperative for creating logical sequence of interventions and documentation, understanding relationships, and outlining shared beliefs and assumptions in a given profession (McEwen \& Wills, 2019). To appropriately capture the wide array of necessary elements in systematic review of patients suffering with ARDS and the selected interventions, a grand nursing theory based on human needs will provide guidance.

Virginia Henderson had an enormous impact in the $20^{\text {th }}$ century as a nursing educator, researcher, and visionary. Her holistic design accounted for the interventions a nurse could provide in any given environment to facilitate the return of a patient's previous level of function and self-care. If devoted, nursing care cannot restore an individual's health, then the nurse will guide the patient into a dignified, peaceful death. "Health was not explicitly defined, but it is taken to mean balance in all the realms of human life" (McEwen \& Wills, 2019, p. 137). Henderson's Nursing Need Theory describes for 14 activities for client assistance: breathe normally, eat and drink adequately, eliminate body wastes, move and maintain desirable postures, sleep and rest, maintain body temperature within normal range, keep the body clean and protect the skin, avoid danger in the environment and avoid injuring others, communicate with others, worship according to one's faith, work in a way that creates a sense of accomplishment, engage in various forms of recreation, and to attain normal development and health with available facilities (McEwen \& Wills, 2019). These activities encompass the four major concepts of person, environment, health, and nursing. 
Henderson's significant contribution to the field of nursing is undisputed. Her works were imbedded in major nursing textbooks for 30 years. Each element in the 14 activities for client assistance can be framed as a research question and guide the approach of the researcher. Additionally, the activities address all potential aspects of an individual, from physiologic, psychologic, sociologic, spiritual, and moral. Thus, the major concepts of Henderson's theory can be applied to guide a variety of studies.

In a research study regarding ARDS and the interventions employed to combat the multiple effects of ARDS, Virginia Henderson's theory will serve as an effective framework. Her chief focus further incorporates Maslow's Hierarchy of Needs to the nursing field. Utilization of the theorized basic needs will help shape the focus of attention and discussion, with three of the physiologic categories particularly in mind: breathe normally, move and maintain desirable postures and to sleep and rest. It is important to consider these physiologic categories when treating patients with severe ARDS, as these individuals are physiologically compromised, and the prescribed treatments may increase the risk for each category's degradation. 


\section{Method}

\section{Purpose}

The purpose of this study is to compare the best evidence regarding current treatment options of prone therapy, neuromuscular blockade, and extracorporeal membrane oxygenation (ECMO) therapy, in decreasing mortality rates for adult patients with severe ARDS. Studies offer support and criticism of each therapy utilization to maximize alveolar recruitment while simultaneously preventing acute lung injury. The PICO approach was used to frame the research question that guides this study: Among patients suffering with severe ARDS, which is more effective between prone therapy, ECMO therapy and neuromuscular blockade in decreasing mortality rates?

\section{Design}

A systematic review was employed for this study, utilizing the Preferred Reporting Items for Systematic Reviews and Meta-Analyses (PRISMA) guideline, to ensure adequate integration of research evidence on the use of prone positioning, neuromuscular blockade and ECMO as chief interventions to reduce mortality rates in ARDS patients. Included in these guidelines is a 27-item checklist to capture the minimum items required for reporting and a 4-phase flow diagram which depicts the literature search strategy (Liberati et al., 2009). All guidelines were adhered to when choosing appropriate studies to include in this systematic review. Framework adopted from Virginia Henderson's grand theory regarding the 14 activities for client assistance will helped in creating an orderly flow of information. Specifically, three of the basic human activities focus on physiologic characteristics that align with this project. The 
physiologic factors of interest are to breathe normally, move and maintain desirable postures and to sleep and rest. Data collected from each study focused on these key features and determine the impact of each treatment method for ARDS.

\section{Inclusion/Exclusion Criteria}

Inclusion criteria were randomized controlled trials (RCT) and meta-analyses in English, conducted within the last ten years. All patients were in the ICU, intubated with a diagnosis of ARDS. Additionally, treatment included prone positioning, use of neuromuscular blockade and/or ECMO. Male and female patients were included. Exclusion criteria were patients who were not diagnosed with ARDS, utilized ECMO or paralytics in non- ARDS patients and individuals less than 18 years of age.

\section{Search Strategy}

To conduct a targeted search for the literature review Google Scholar, PubMed, Cochrane library, and the CINAHL databases were used to find appropriate articles. These search engines provided articles from the New England Journal of Medicine, Mediators of Inflammation, Respiratory Care, the Journal of Clinical Medicine Research and Cureus. Both the ancestry approach and keyword search with Boolean operators were employed. Keywords utilized in this search included acute respiratory distress syndrome (ARDS), ARDS physiology, prone therapy, neuromuscular blockade ARDS, extracorporeal membrane oxygenation (ECMO) therapy, and ECMO therapy ARDS.

Each article was screened for the decided inclusion and exclusion criteria utilizing the PRISMA flow diagram (see Figure 1). The goal of this review was to provide a 
summary of evidence on each component of the research problem and the most effective treatment in reducing mortality in patient's diagnosed with severe ARDS. 


\section{Figure 1}

Four-phase flow diagram for PRISMA (Liberati et al., 2009)

\section{PRISMA 2009 Flow Diagram}
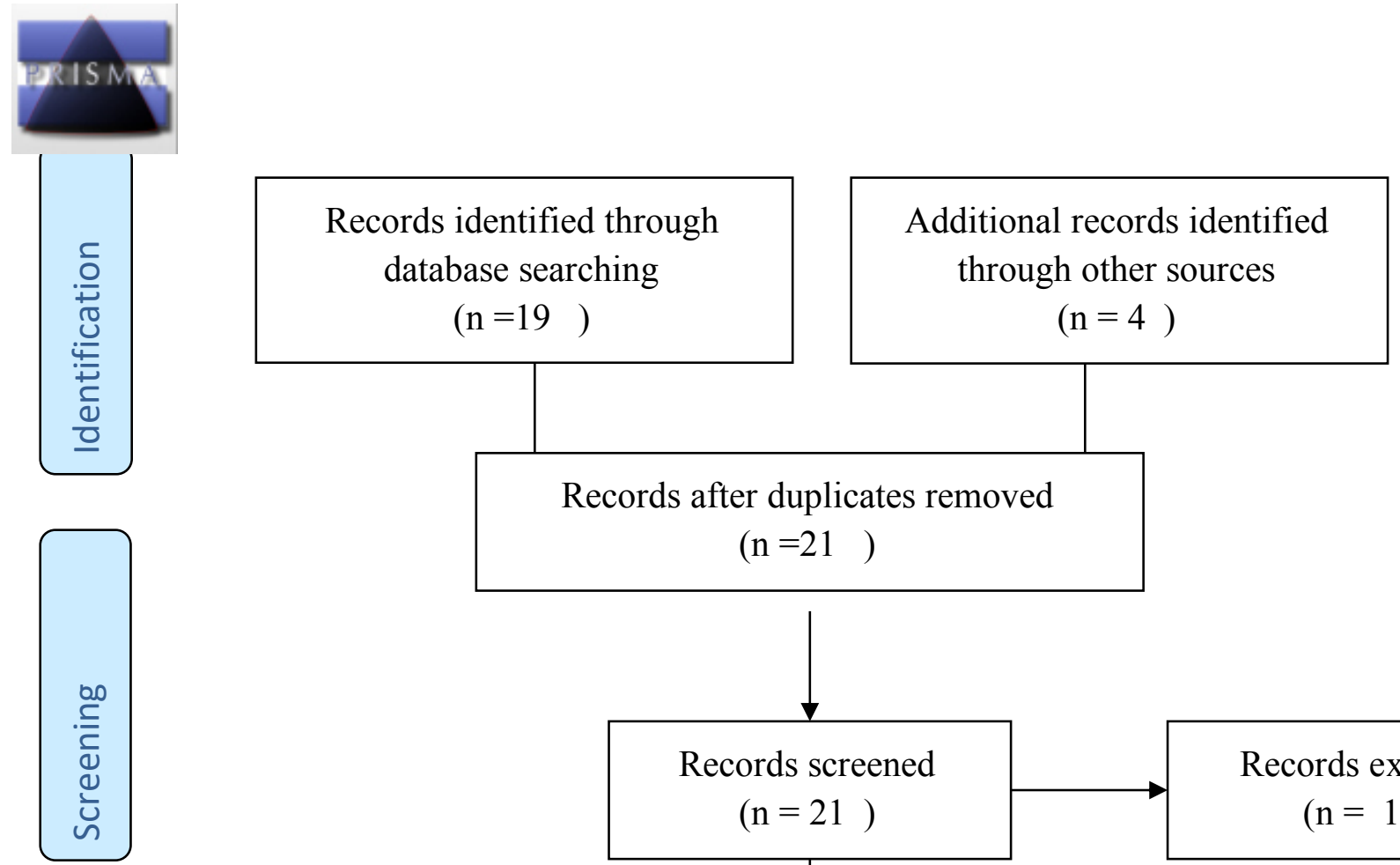

Records after duplicates removed $(\mathrm{n}=21)$
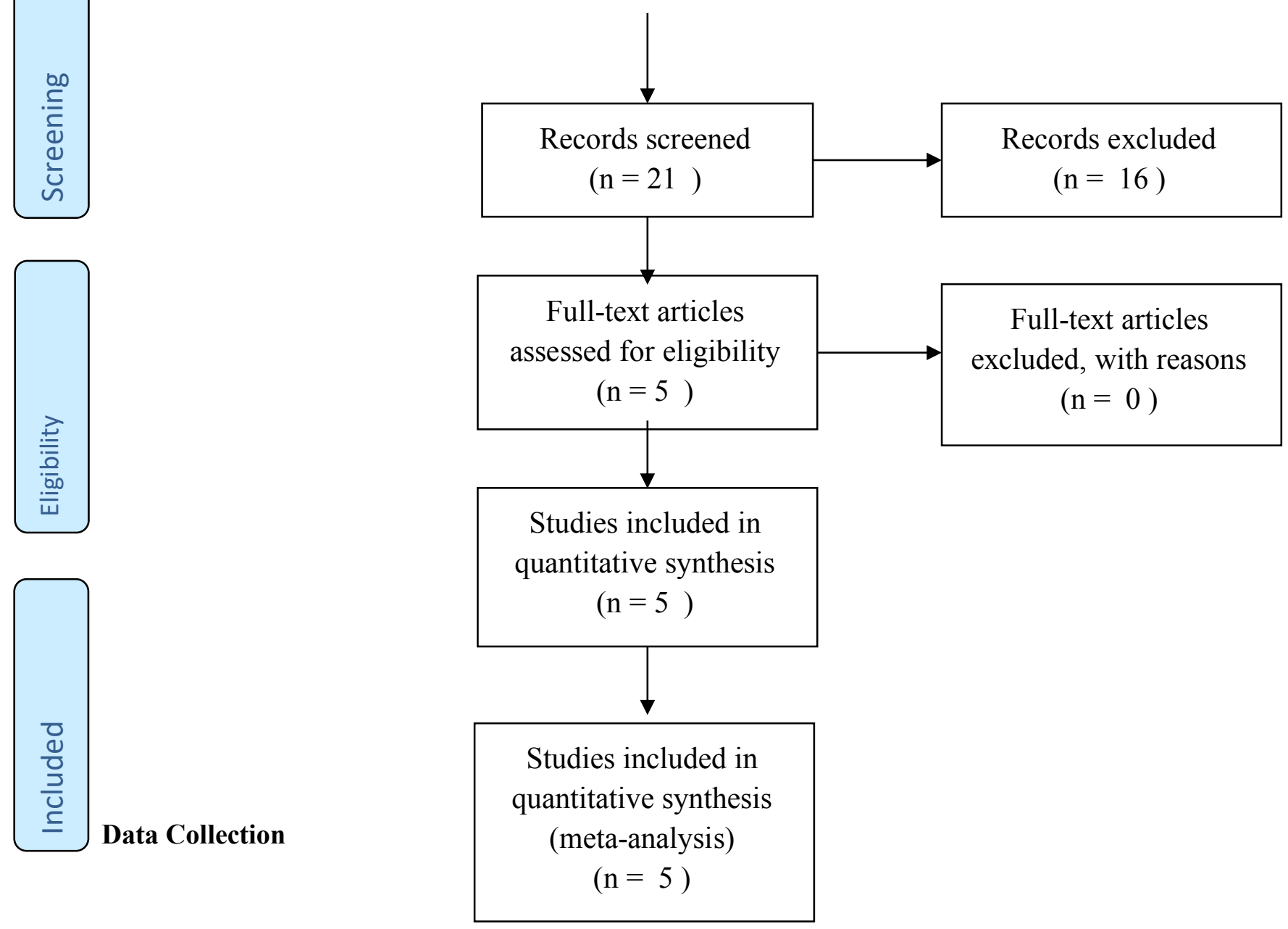
A summary table of the selected articles was created with pertinent information about each study, including aim, type of study, design, population, methods, data collection, determined level of evidence, data analysis, results/outcomes, and mortality rate at day 28,60 , and 90 . These specific time frames were observed in the reviewed studies and incorporated in this systematic review. Included studies were also screened for the seven specific elements from Virginia Henderson's 14 activities of client assistance and needs. The theorized basic needs are the focus of discussion for patients who survive ARDS, with three of the physiologic categories particularly in mind: breathe normally, move and maintain desirable postures and to sleep and rest.

\section{Critical Appraisal}

Critical appraisal of each article assisted in the extraction of the strengths and weaknesses offered in each review. A guide to overall critique of a quantitative research is provided by Polit and Beck (2017), which includes report title, abstract, problem statement, hypothesis or question, literature review, framework, methods, results, discussion, and general issues. Additionally, this research will adhere to the PRISMA guidelines and each study will be appraised with the Critical Appraisal Skills Programme (CASP) to ensure integrity of the analysis. Following individual study appraisal and analysis a cross study analysis will be performed. 


\section{Plan for Analysis}

A systematic review requires the transformation of integrated quantitative data into a comprehensive display of results. Collected data was entered into a cross analysis table where it was organized by themes and patterns (Figure 2). With the data in such a form, it aids in the comparison of pertinent outcomes for all studies under examination.

Figure 2.

Cross Analysis

\begin{tabular}{|c|c|c|c|c|c|}
\hline \multirow[t]{2}{*}{$\begin{array}{l}\text { Author, } \\
\text { Year }\end{array}$} & \multicolumn{3}{|c|}{ Mortality Rate at Day: } & \multicolumn{2}{|c|}{$\begin{array}{c}\text { Median Length of Stay } \\
\text { (LOS) in Days }\end{array}$} \\
\hline & 28 & 60 & 90 & $\begin{array}{l}\text { Intensive } \\
\text { Care Unit } \\
\text { (ICU) }\end{array}$ & Hospital \\
\hline
\end{tabular}

Next, the results will be addressed. 


\section{Results}

In order to select articles applicable for this systematic review, the PRISMA checklist (Appendix A) and the PRISMA flowchart (Figure 1) were utilized. The original search yielded 24 studies. After elimination of duplicate articles, 21 remained for further review. Abstracts were then considered, and inclusion and exclusion criteria were organized, which removed 16 more articles from this systematic review. The remaining five, full text articles were considered in their entirety. Five total RCTs remained for inclusion in this systematic review. Crucial elements were ordered in study collection tables (Appendix B) and critically appraised using the CASP checklist (Appendix D). The subsequent cross study analysis is displayed in the following section (Appendix E).

\section{Neuromuscular Blockade}

In a multicenter, double-blind trial, Papazian et al. (2010) (Appendix B 1) sought to determine if an early introduction of neuromuscular blockade in ARDS patients would improve clinical outcomes and mortality. Patients were selected between March 2006 to March 2008 from 20 ICU's in France. The subjects would have demonstrated acute hypoxemic respiratory failure within 48 hours of endotracheal tube placement. Diagnosis of ARDS was established if certain parameters were met, namely a $\mathrm{PaO}_{2} / \mathrm{FiO}_{2}$ (P:F) ratio of less than $150 \mathrm{mmHg}$ with a tidal volume of 6-8 milliliters $(\mathrm{ml})$ per kilogram $(\mathrm{kg})$ of ideal body weight and a PEEP of at least $5 \mathrm{cmH}_{2} \mathrm{O}$. In addition, these patients had to have demonstrated a lack of left atrial hypertension, captured either by a pulmonary wedge pressure reading or on an echocardiogram. Originally, 1326 patients were examined for eligibility. Once exclusion criteria were applied, 986 patients were removed from the 
trial. Reasons for exclusion were for age less than 18 years, pregnancy, lack of consent, ongoing infusion of neuromuscular blockade during enrollment, increased intracranial pressure, enrollment in another study within the previous month, severe, chronic disease requiring ventilation at home, chronic and severe liver disease, actual body weight exceeding $1 \mathrm{~kg}$ per $\mathrm{cm}$ of height, chemotherapy-induced neutropenia, bone marrow transplantation, time frame window missed, pneumothorax, and expected duration of mechanical ventilation of less than 48 hours.

This trial ultimately secured a large host of 340 adult patients randomly divided into two groups; 178 destined to receive cisatracurium besylate and 162 that were bound to receive placebo administration, each for 48 hours. Several baseline characteristics of the patients were illustrated. A few to note were that the cisatracurium group had a mean age of $56 \pm 16$ and average P:F ratio of $106 \pm 36$. In the placebo group, the mean age was $58 \pm 15$ and average P:F ratio of $115 \pm 41$. The primary endpoint observed was patient death either before hospital discharge or within 90 days of enrollment. Secondary outcomes were as follows: 28-day mortality, number of days without organ or system failure between day 1 and day 28, number of days spent outside the ICU between days 128 , rate of ICU acquired paresis, rate of barotrauma, number of ventilator free days between days 1-28 and days 1-90, and MRC (Medical Research Council) scores on day 28 and on the day of ICU discharge. Hazard ratio was determined in the cisatracurium compared to the placebo group for death at day 90 as 0.68 (95\% confidence interval [CI]). Crude 90 -day mortality was also calculated to be $40.7 \%(95 \% \mathrm{CI})$ in the placebo group and $31.6 \%(95 \% \mathrm{CI})$ in the cisatracurium group. Mortality at days 28 was $23.7 \%$ 
$(95 \% \mathrm{CI})$ in the cisatracurium group and $33.3 \%(95 \% \mathrm{CI})$ among the placebo group (Appendix C 1).

The author cited some limitations. Only cisatracurium was utilized and no other neuromuscular blocking agent was studied. Additionally, the researchers tested the use of this drug in early ARDS only and not in late ARDS. The conclusion of this study demonstrated that early use of neuromuscular blockade (within 48 hours of ARDS diagnosis) in ARDS patients with low tidal volume ventilation may improve clinical outcomes. Low tidal volume ventilation refers to maintaining tidal volumes of 6-8 milliliters ( $\mathrm{ml})$ per kilogram $(\mathrm{kg})$ of ideal body weight.

Critical analysis of the Papazian et al. (2010) study using the CASP checklist (Appendix D 1) revealed a less precise treatment effect than desired. The cisatracurium group had an absolute reduction of $9 \%$ in mortality at day 90 or discharge, however, the study was ultimately underpowered. The sample size of this study was based on comparisons to two earlier groups. Since the mortality of the placebo group in this study was lower than that of the control group in earlier studies, this study was underpowered. To account for this deficit, 855 patients would have been required to produce an $80 \%$ statistical power.

In a multicenter, unblinded, randomized control trial, Moss et al. (2019) (Appendix B 5) sought to determine the benefits of early administration of continuous neuromuscular blockade in mechanically ventilated patients with moderate to severe ARDS (ROSE trial). Moderate to severe ARDS was characterized in this study by a P:F ratio of $<150 \mathrm{mmHg}$ while on a PEEP of $\geq 8 \mathrm{cmH}_{2} \mathrm{O}$. Patients were randomly assigned 
in a 1:1 ratio to the intervention group or the control group. Both groups underwent low tidal volume ventilation with PEEP of at least $8 \mathrm{~cm}$ of water within two hours of randomization. Patients would maintain the ventilator settings for up to five days. If the patient demonstrated hypoxia, Pplat of greater than $30 \mathrm{cmH}_{2} \mathrm{O}$, hypotension, or a $\mathrm{pH}$ of $<$ 7.15, the PEEP was allowed to be lowered. If selected for the intervention group, the patient would have achieved deep sedation within four hours, followed by a $15 \mathrm{mg}$ bolus of neuromuscular blockade (cisatracurium), then $37.5 \mathrm{mg}$ per hour continuous infusion of cisatracurium for 48 hours. The control group would receive usual-care approach without cisatracurium and with lighter sedation targets. Light sedation targets were measured by the Richmond Agitation-Sedation Scale (RASS score 0 to -1), Riker Sedation-Agitation Scale (3-4), or the Ramsay Sedation Scale (2-3).

The ROSE trial (2019) screened 4848 patients between January 2016 to April 2018 in 48 hospitals around the United States. Inclusion criteria included mechanically ventilated patients with a $\mathrm{P}: \mathrm{F}$ ratio of $<150 \mathrm{mmHg}$ while on a $\mathrm{PEEP}$ of $\geq 8 \mathrm{cmH}_{2} \mathrm{O}$, noncardiac related respiratory failure, and bilateral opacities on chest x-ray/computer tomography (CT) that ruled out pulmonary effusions, pneumothorax, or nodules. Patients were excluded from the trial if the P:F ratio improved before enrollment or if the patient had prior administration of neuromuscular blockade. Once inclusion and exclusion criteria were applied, a total of 1006 patients remained for the study; 501 randomly assigned to the cisatracurium group and 505 randomized to the control group. Prone positioning and/or glucocorticoid administration were permitted as well.

The primary end point was death from any cause in the hospital at 90 days. In the intervention group, 213 patients $(42.5 \%)$ died within that period of time and 216 patients 
$(42.8 \%)$ from the control group $(\mathrm{P}=0.93)$. At the second interim anaylsis, this trial was stopped for futility. Secondary end points compared the intervention group versus the control group at day 28 regarding mortality (184 vs. 187), ventilator-free days $(9.6 \pm 10.4$ vs. $9.9 \pm 10.9)$, days out of the hospital ( $5.7 \pm 7.8$ vs. $5.9 \pm 8.1)$ and days out of the ICU $(9.0 \pm 9.4$ vs. $9.4 \pm 9.8)$, which displayed no statistical significant differences between the two groups (Appendix C 5). Prone positioning and/or glucocorticoid administration were utilized similarly in both groups.

This trial had both strengths and weaknesses, as well as limitations. One strength was the strong staff compliance with the protocol, which aided in consistent ventilator strategies used. This was also a large multicenter study and the subjects were randomized to study groups. The trial was not blinded to the healthcare professionals. Another weakness is that the ROSE trial was stopped early for futility, which renders it an underpowered study. Traditional measurement of neuromuscular blockade with the TOF measurements was not utilized in this study. Lastly, it is noted that the uncontrolled use of prone positioning may have falsely affected the mortality rate.

Critical appraisal of the ROSE trial revealed a specific focus in the study and that all the patients were randomized. The participants were all accounted for, baseline characteristics were similar in both groups, and aside from the designated experimental intervention, both groups were treated equally. This was not a blinded trial. With regard to the treatment effect, at day 90 , any cause of in-hospital death occurred in 213 patients $(42.5 \%)$ in the cisatracurium group and 216 patients $(42.8 \%)$ in the control group $(\mathrm{P}=$ 0.93). Also, at a two-sides alpha level of 0.05 , it was calculated that 1408 patients would be needed in order for the trial to have $90 \%$ statistical power. Researchers were able to 
include 1006 patients, however, by the second interim analysis, the trial was stopped for futility.

\section{Venovenous ECMO}

Peek et al. (2010) created a multicenter, randomized controlled trial with two arms in order to determine the efficacy of conventional ventilation support versus ECMO for severe adult respiratory failure (CESAR trial) (Appendix B 2). If entered into the ECMO arm, the individual was transferred to an ECMO specialist center (not transferred on ECMO). If the patient was hemodynamically stable, a standard protocol was applied, including pressure restricted mechanical ventilation, and use of PEEP and $\mathrm{FiO}_{2}$ to maintain oxygen saturation to greater than $90 \%$, use of diuretics, and prone positioning. After 12 hours, if patient did not positively respond to treatment with proof of maintained oxygen saturation and/or $\mathrm{pH}$ measurement of less than 7.2, cannulation for ECMO was placed. Once ECMO was utilized, it was conducted in the veno-venous mode and was continued until lung recovery or apparent irreversible multiorgan failure ensued. Patients entered into the conventional management $(\mathrm{CM})$ would receive continuous conventional ventilation, typically on a pressure control mode, with low-volume low-pressure ventilation.

Patients were enrolled from 68 different centers in the United Kingdom (UK) from 2001 to 2006. In this study, the severity of ARDS was measured with the Murray scoring system, which considers four criteria that lead to the development of ARDS; hypoxemia, respiratory system compliance, chest radiographic impression, and level of PEEP (Raghavendran \& Napolitano, 2011). Patients score from 0-4, with 4 rating as the 
most severe form of ARDS. In the beginning, 766 patients from 148 centers were eligible for consideration. To be included in the trial, patients required a Murray score of three or more or a $\mathrm{pH}$ of less than 7.2 and uncompensated hypercapnia despite ideal ventilator use. Additionally, all patients in the trial were between the ages of 18-65. Patients were excluded if $\mathrm{FiO}_{2}$ was set greater than $80 \%$ or peak pressure was greater than $30 \mathrm{cmH}_{2} \mathrm{O}$ for seven days. Patients were also excluded for signs of intracranial bleeding, if there were contraindications for heparin administration, or if any contraindications existed for continuation of active treatment. Ventilator settings were assessed on an hourly basis.

One hundred eighty patients from 68 centers met the inclusion criteria and were entered into the CESAR trial. Ninety patients were randomized to conventional ventilator support and the remaining 90 were randomized to receive ECMO treatment. The baseline characteristics between the two groups were similar with a leading cause for ARDS being pneumonia in approximately $2 / 3$ of the total patients. Some that were elected to participate in the ECMO group did not ultimately receive ECMO therapy. Following standardized treatment of ARDS patients, which was to occur prior to ECMO therapy, 17 patients no longer qualified for ECMO. Five other patients died before or during transport to the designated ECMO center. Mean Murray scores between the ECMO group that received therapy, the ECMO group that did not, and control $(\mathrm{CM})$ group were $3.4 \pm 0.3$, $3.6 \pm 1.3$, and $3.4 \pm 0.3$, respectively.

The primary end point in this trial was survival at 6 months without severe disability. Note that severe disability was defined as confinement to a bed and no longer able to wash or dress alone. Severe disability No death or severe disability was observed in 57 patients in the ECMO group and 41 in the CM group, creating a relative risk of 0.69 
(95\%CI 0.05 to 0.97 ) with $p=0.03$. This finding is statistically significant. The study is missing information on three patients. Fifty-seven patients in the ECMO arm died in less than 6 months or died before discharge and 45 in the CM arm. This created a relative risk of $0.73(95 \% \mathrm{CI} 0.52-1.04)$ with a $\mathrm{p}=0.07$. This finding was not statistically significant. Secondary outcomes consisted of ECMO patients who were proned (4\%) versus patients in the $\mathrm{CM}(42 \%)$ with a $\mathrm{p}=0.58$. Another secondary outcome considered was median ICU days in both the ECMO and the CM arm, which was 24 ICU days versus 13 ICU days, respectively. Median hospital days in each group was 35 in ECMO arm and 17 CM arm. (Appendix C 2). Strengths and weaknesses are also noted. Ultimately, this study provided evidence that patients that fit the inclusion criteria who fail optimal conventional ventilator management should be transferred to an ECMO specialist center for ECMO treatment to decrease the likeliness of death or severe disability.

Critical appraisal of the CESAR trial (Peek et al., 2010) (Appendix D 2) revealed the original power calculations were based on anticipated $70 \%$ mortality prediction in the control group. The researchers considered a $10 \%$ chance of severe disability in both arms and determined 240 total patients were required. Sample size review conducted in 2003 revealed only $60 \%$ of target size was attained. It was agreed that a lower sample size of 180 patients would be enough to detect a reduction by $1 / 3$. Mortality in the ECMO arm was lower than the conventional arm, however it did not reach statistical significance.

In the Combes et al. (2018) (Appendix B 4) international, multicenter randomized control trial, researchers sought to determine the efficacy of venovenous ECMO in patients with severe ARDS (EOLIA trial). Patients were determined to have severe ARDS if, under the conditions outlined by the American-European Consensus 
Conference (Bernard et al., 1994), one of the three following criteria were met; an arterial blood $\mathrm{pH}$ of less than 7.25 with a partial pressure of carbon dioxide of at least $60 \mathrm{mmHg}$ for over six hours, a P:F ratio of less than $50 \mathrm{mmHg}$ for more than 3 hours, or a P:F ratio of less than 80 for more than six hours. Randomization was stratified according to the duration of ventilation before randomization and according to the center in which the patients were being treated. A centralized, web-based randomization system ensured concealment of patient assignments. Exclusion criteria applied if the patient was ventilated more than 7 days, if the subject was less than 18 years old, had a body mass index (BMI) over 45, cardiac failure resulting in ECMO, long term respiratory insufficiency, history of heparin induced thrombocytopenia, life expectancy less than five years due to cancer, a Simplified Acute Physiology Score (SAPSII) (Le Gall, 1993) of more than 90, cardiac arrest resulting in coma, irreversible neurologic injury, expected difficulty obtaining vascular access for ECMO, or the withdrawal of life sustaining treatment.

Enrolled patients were all intubated via endotracheal tube for less than 7 days. Patients randomized to the venovenous ECMO group would have percutaneous cannulas placed and adjustments made via the ECMO device to maintain a $\mathrm{P}_{\mathrm{a}} \mathrm{O}_{2}$ between 65-90 $\mathrm{mmHg}$, an arterial oxygen saturation $\left(\mathrm{SaO}_{2}\right)$ of greater than $90 \%$, and a $\mathrm{PaCO}_{2}$ of less than $45 \mathrm{mmHg}$. Mechanical vantilation during ECMO was set to an $\mathrm{FiO}_{2}$ of $30-50 \%$, a PEEP of $10 \mathrm{cmH}_{2} \mathrm{O}$, respiratory rate of 10-30 breaths per minute, and a tidal volume adjusted to maintain a plateau pressure (Pplat) of $24 \mathrm{cmH}_{2} \mathrm{O}$ or less (high pressure level of $24 \mathrm{cmH}_{2} \mathrm{O}$ or less if in bilevel positive airway pressure-release ventilator mode). An anticoagulation target APTT of 40-55 or anti Xa of 0.2-0.3 with heparin was 
implemented as well. Patients in the control group were on a volume-assist-controlled ventilation with an $\mathrm{FiO}_{2}$ set to obtain an $\mathrm{SaO}_{2}$ between $88-95 \%$ and a of $55-80 \mathrm{P}_{\mathrm{a}} \mathrm{O}_{2}$ $\mathrm{mmHg}$, PEEP set to ensure a Pplat not to exceed 28-30 $\mathrm{cmH}_{2} \mathrm{O}$, tidal volume set to $6 \mathrm{ml}$ per $\mathrm{kg}$ of ideal body weight, and respiratory rate set as high as 35 breaths per min. It was strongly encouraged to utilize neuromuscular blockade and prone positioning in this group. Sodium bicarbonate infusions and predetermined ventilator adjustments could be made to ensure target goals in the individual's $\mathrm{pH}, \mathrm{PaCO}_{2}$, and Pplat. Cross over from control to ECMO was possible if the patient maintained a $\mathrm{SaO}_{2}$ of less than $80 \%$ over 6 hours.

The EOLIA trial evaluated 1015 patients for eligibility with an aim for a target sample of 331 individuals. After the fourth interim analysis, the data safety monitoring board (DSMB) recommended to stop the trial after only 249 patients, according to the preset futility stopping rules. It was determined that this trial was unlikely to reach a definitive result. The ECMO group had 124 patients and the control group had 125 patients. This study was executed in 64 centers, mostly across France, and included some ECMO centers and some non-ECMO centers. The non-ECMO centers were to have extensive practice in treating ARDS patients as well as the ability to establish ECMO treatment within two hours of randomization.

The primary end point measured was mortality at 60 days, which displayed 44/124 (35\%) from the ECMO group and 57/125 (46\%) from the control group. No significant statistical difference is noted, with a relative risk of $0.76(95 \% \mathrm{CI}, 0.55-1.04)$ and $\mathrm{P}$ value of 0.09 . Secondary endpoints when comparing the ECMO group to the control group, consist of a lower relative risk of treatment failure 0.62 (95\% CI, 0.47 to 
$0.82 ; \mathrm{P}<0.001$ ), which was death by day 60 , more days spent without prone positioning (59 vs. 46 days), and more without renal replacement therapy (50 vs. 32 days). Additionally, the ECMO group spent more days than the control group free of cardiac failure and renal failure. Less patients from the ECMO group versus the control group required the other available interventions such as prone positioning, recruitment maneuvers, inhaled nitric oxide or prostacyclin, or glucocorticoids. However, more patients in the ECMO group, suffered significantly more bleeding events than that of the control group ( $46 \%$ vs. $28 \%$ ), higher rates of severe thrombocytopenia ( $27 \%$ vs. $16 \%$ ), and fewer cases of ischemic stroke (Appendix C 4).

Limitations, strengths and weaknesses were identified. One limitation was that the trial was stopped short of the calculated sample size by 82 patients, which only secured $75 \%$ of their goal. The sample size was halted due to predetermined restrictions set in place based on futility. A definitive result based on this trial was unlikely. Another limitation was that $28 \%$ of patients crossed over from the control group to the ECMO group, which created an inadequate picture of the ECMO data results. A strength presented in the EOLIA trial was that it is the largest multicenter ECMO study to be conducted since the CESAR trial . Additional strengths include the use of standardized criteria and protocols which enabled consistent treatments in both ECMO management and ventilator strategies. The criteria utilized by the researchers also ensured that $98 \%$ of patients selected for the ECMO arm did receive ECMO therapy. One weakness identified was that this trial included individuals treated at ECMO and non-ECMO centers. Additionally, the trial was underpowered to detect mortality. 
Critical analysis of the EOLIA trial (Appendix D 4) reveals that the trial did focus on a particular intervention, patients were randomized for the trial, and all patients were properly accounted for. Medical and nursing staff were not blinded however, research staff members were blinded. Baseline characteristics of each group were similar. Patients who received ECMO were treated in ECMO and non-ECMO institutions. With regard to the treatment effect, at day 60 , mortality in the ECMO group was $35 \%$ compared to $46 \%$ in the control group. Sixty-day mortality was not significantly lower in the ECMO group. The estimated treatment effect measured at an alpha level of 5\% and with groupsequential analysis after randomization of 60 patients, the maximum sample would have needed to be 331 to have an $80 \%$ power. At the fourth planned sequential interim analysis, the trial was stopped in accordance with prespecified rules, leaving 249 patients in the trial. Results can be applied to local populations and all clinically important outcomes were considered. In conclusion, the benefits of ECMO did not outweigh the harms and costs.

\section{Prone Positioning}

A multicenter, prospective, randomized control trial (Guérin et al., 2013) was created to determine the outcomes of early application of prone positioning in patients with severe ARDS (PROSEVA trial) (Appendix B 3). Researchers in this study defined severe ARDS consistently with American-European Consensus Conference criteria (Bernard et al., 1994) which requires a patient to display a P:F ratio of $<150 \mathrm{~mm} \mathrm{Hg}$, with an $\mathrm{FiO}_{2}$ of $\geq 0.6$, a PEEP of $\geq 5 \mathrm{cmH}_{2} \mathrm{O}$, and a tidal volume of about $6 \mathrm{ml}$ per kilogram of predicted body weight. These patients were randomized via the use of a centralized Web-based management system to be in the prone or supine group after 12-24 
hours of observation and stabilization. Patients in the supine group were in a semirecumbent position and physiologic measurements were assessed every six hours. Those randomized to the prone group were turned to the prone position for $\geq$ to 16 hours. This intervention was repeated for $\geq$ to 28 days. Prone positioning was ceased if the P:F ratio was $\geq 150 \mathrm{mmHg}$ with a PEEP $\leq 10 \mathrm{~cm} \mathrm{H}_{2} \mathrm{O}$ and $\mathrm{FiO}_{2} \leq 60 \%$ for $\geq 4$ hours after the prior prone positioning, complications during prone positioning, or decreased $\mathrm{P}: \mathrm{F}$ ratio before two consecutive prone sessions. Note that mechanical ventilation was modeled after ARDSnet (n.d.) low tidal volume protocol, with a goal $\mathrm{pH}$ of 7.20-7.45 and end inspiratory plateau pressure goal $\leq 30$.

The PROSEVA trial enrolled patients between 2008-2011 from 26 ICUs in France and one in Spain. To be included in the study, patients must display a P:F ratio of $<150 \mathrm{~mm} \mathrm{Hg}$, with an $\mathrm{FiO}_{2}$ of $\geq 0.6$, a PEEP of $\geq 5 \mathrm{cmH}_{2} \mathrm{O}$, and a tidal volume of about $6 \mathrm{ml}$ per kilogram of predicted body weight. These patients also had an endotracheal tube in place and mechanically ventilated for less than 36 hours. Reasons for exclusion were intracranial pressure of $>30 \mathrm{mmHG}$, cerebral perfusion pressure $<60 \mathrm{mmHg}$, a mean arterial pressure of $>65 \mathrm{mmHg}$, massive hemoptysis, recent tracheal surgery, facial trauma, recent permanent pacemaker placement, recent deep vein thrombosis, unstable fractures of spine, pelvis, or femur, lung transplant, pregnancy, large body surface area burns, anterior chest tube with air leak, diseases resulting in life expectancy less than one year, end-of-life decision, prone positioning prior to inclusion, or nitric oxide, almitrine bismesylate, or ECMO therapy. 
Guérin et al. (2013) was able to secure 466 patients total, with randomization resulting in 229 in the supine group and 237 in the prone group. Baseline characteristics between the two groups were similar. The prone group was $70 \%$ male with a mean age of $58 \pm 16$. The supine group was $66.4 \%$ male with a mean age of $60 \pm 16$. Those with sepsis in the prone group were $82.2 \%$ and $85.2 \%$ in the supine group $(\mathrm{p}<0.05)$. Additional interventions for consideration were vasopressors (prone $72.6 \%$ and supine $83 \%, \mathrm{p}<$ 0.05), neuromuscular blockade (prone $91 \%$ and supine $82.3 \%, \mathrm{p}<0.05$ ), continuous renal replacement mean of $17.1 \%$ and mean use of glucocorticoids at $44.9 \%$.

Primary end point was 28 -day mortality, with prone group averaging $16 \%$ and the supine group at $32.8 \%(\mathrm{p}<0.001)$. Secondary outcomes in supine vs. prone were mortality from any cause at 90 days (41\% vs. $23.6 \%, 95 \%$ CI $0.29-0.67, \mathrm{p}<0.001)$, successful extubation at 90 days (65\% vs. $80.5 \%, 95 \%$ CI $0.29-0.70, \mathrm{p}<0.001)$, time to successful extubation in survivors (19 vs. 17 days, $p=0.87$ ), time to successful extubation in non-survivors (16 vs. 18 days), ventilator-free days at day 28 (10 vs. 14, p < 0.001 ), ventilator-free at day 90 (43 vs. $57, \mathrm{p}<0.001)$, pneumothorax $(5.7 \%$ vs. $6.3 \%$, $95 \% \mathrm{CI} 0.39-2.02, \mathrm{p}=0.85)$, noninvasive ventilation at 28 days $(4.7 \%$ vs. $1.8 \%, 95 \% \mathrm{CI}$ $0.27-1.86, \mathrm{p}=0.37)$, and noninvasive ventilation at 90 days $(8.1 \% \mathrm{vs} .6 .4 \%, 95 \% \mathrm{CI}$ 0.36-1.67, $\mathrm{p}=0.59$ ) (Appendix C 3). Some strengths to note were that the researchers had an appropriate power calculation and that the ventilation strategy, including the weaning strategy, was standardized with a table to determine PEEP and $\mathrm{FiO}_{2}$. One weakness in this study was that all of the centers selected had greater than five years of experience in proning patients, therefore the success of this intervention may not be applicable to all institutions. Another weakness was the difference in baseline characteristics between the 
two groups, namely the SOFA score, use of vasopressors, and use of neuromuscular blockade.

Critical analysis of the PROSEVA trial (Guérin et al., 2013) (Appendix D 3) displayed the prone group had a 51\% relative reduction and $17 \%$ absolute reduction in 28-day mortality compared to the supine group. Additionally, the power calculation was appropriate, with an estimated sample of 456 patients would generate a $90 \%$ power to detect an absolute reduction of 15 percentage points with prone positioning. Referring to the baseline characteristics of the two groups, all were fairly even. Ultimately, the benefits outweigh the harms and costs, and early and long sessions of prone positioning is considered to improve mortality in patients with severe ARDS.

Next, summary and conclusions will be addressed. 


\section{Summary and Conclusions}

Acute Respiratory Distress Syndrome is a major concern in hospitals and carries a reported mortality rate of approximately $40-50 \%$ with up to 150,000 cases diagnosed in the United States annually (El-Haddad et al., 2017). Councils have been formed to accurately measure the severity of ARDS, most notably the American-European Consensus Conference, which outlined criteria to categorize a patient with mild to severe ARDS and a standardized definition facilitated the conduct of ARDS research. Interventions and therapies have been studied on a large scale to determine the best, most consistent method to decrease morbidity and mortality rates in this population. This systematic review focused on randomized control trials (RCT), evaluating three widely used interventions for severe ARDS including prone positioning for improved oxygen recruitment, resting the pulmonary system with venovascular ECMO support, and sedating with a neuromuscular blockade.

This systematic review was intended to examine which intervention, between prone positioning, ECMO, or neuromuscular blockade, decreases mortality rates most reliably among patients with severe ARDS. In many studies, multiple interventions were used simultaneously. A comprehensive search was done using Google Scholar, PubMed, Cochrane library, and the CINAHL databases to find appropriate articles. To ensure a methodical selection of studies, the PRISMA checklist (Appendix A) and the four-phase diagram (Figure 1) were utilized. After careful examination of various journal articles, five randomized control trials were selected for this systematic review. In order to organize the data available in each trial, study collection data and outcome data collection were constructed to extract and tabulate applicable information (Appendices B1- B5 and 
C1- C5). In order to critique each study and apply the evidence to this systematic review and the Critical Appraisal Skills Programme (CASP) checklist was utilized (Appendices D1- D5). Finally, the key findings were reduced to a cross analysis table for comparison to satisfy the primary objectives of this review (Appendix E). The primary objectives obtained regarded mortality rate at days 28, 60 and 90 and length of stay (LOS) in the intensive care unit (ICU) and in the hospital overall.

In the cross analysis (Appendix E), comparisons of the selected trials were made. The RCTs that failed to decrease ARDS mortality rates across all time periods were Combes et al. (2018) in the EOLIA trial and Moss et al. (2019) in the ROSE trial. Mortality at day 28 in the intervention group versus the control group were measured in the Papazian et al. (2010) to be $23.7 \%$ versus $33.3 \%$ with a $P$ value of 0.05 , in the Guérin et al. (2013) to be $16 \%$ and $32.8 \%$ with a P value of $<0.001$, and in Moss et al. (2019) to be $36.7 \%$ and $37 \%$. Prone positioning demonstrated the greatest decrease in mortality rate at day-28 among the included studies. At day 60, mortality was measured in the intervention group versus the control group in Guérin et al. (2013) to be $23.6 \%$ and $41 \%$ with a $\mathrm{P}$ value $<0.001$ and Combes et al. (2018) as $35 \%$ versus $46 \%$ with a $\mathrm{P}<0.09$. Prone positioning, again, demonstrated a greater decrease in mortality rate at day-60 in those that reported such findings. At day 90, mortality was measured between the intervention group and control group in Combes et al. (2018) to be $37 \%$ versus $47 \%$ and in Moss et al. (2019) as $213(42.5 \pm 2.2)$ versus $216(42.8 \pm 2.2)$ with a P value of 0.93. Between the two studies which measured mortality rate at day-90, there was no significant difference. Length of stay (LOS) in the ICU was calculated as median days in the intervention versus control group in Peek et al. (2010) as 24 versus 13, in Guérin et al. 
(2013) to be $24 \pm 22$ versus $26 \pm 27$ with a reported $\mathrm{P}$ value of 0.05 , and in Combes et al. (2018) to be 23 versus 18 . In regard to hospital LOS between the intervention group and control group, which was reported in only two of the studies, in Peek et al. (2010) was 35 versus 17 median days and in Combes et al. (2018) to be 36 versus 18 median days. Peek et al. (2010) demonstrated the shortest median length of stay in the ICU in the control group and was almost identical with Combes et al. (2018) on median length of stay in the control group in the hospital.

Adverse events were considered and recorded in each trial as well. Every patient in the selected RCTs in this systematic review were intubated via endotracheal tube and on mechanical ventilation. Additionally, all of the patients included satisfied the American-European Consensus Conference definition or the Murray scoring system for severe ARDS. Ventilator setting choices followed the current standard of care guidelines for ARDS, primarily aiming for low volume and low pressure. Subsequently, similar adverse events were reported in each study, for example ventilator-associated pneumonia (VAP), barotrauma, pneumothorax, as well as successful time to extubation, and noninvasive ventilation. All studies proved to have comparable results. The ACURASYS trial displayed greater incidences of barotrauma and pneumothorax in the control group compared to the other studies. Additionally, the two ECMO trials did not include barotrauma and pneumothorax complication data to compare. Additional adverse events included thrombocytopenia, pneumonia, cardiovascular events, bleeding, various types of strokes, hypothermia, and multiorgan failure. Bleeding was a significant risk in the CESAR and EOLIA trials, as ECMO therapy utilizes large bore vascular canulation systems and anticoagulants. Paresis and weakness acquired in the ICU measured highest 
in the ACURASYS and ROSE trials due to the use of neuromuscular blockade in each intervention group. The ROSE trial, however, had fewer events of paresis/weakness, likely due to the lighter sedation targets included in the protocol utilized.

Across the included RCT's, additional ARDS interventions were combined. Prone positioning was included in all of the studies as an adjunct therapy, except in Guérin et al. (2013) as it was the primary intervention used. Combes et al. (2018) in the latest ECMO study and Moss et al. (2019) in the most recent neuromuscular blockade trial were unable to determine whether or not prone positioning played a role in some of the positive outcomes measured. A shared ARDS intervention was the use of neuromuscular blockade in the PROSEVA trial, which did not exclusively discuss its relevance in mortality rate outcomes. In both the ACURASYS and ROSE trial, cisatracurium was the drug of choice for neuromuscular blockade and neither trial utilized the TOF method to monitor level of paralysis.

This systematic review identified several study limitations. First, only five studies existed which met the inclusion and exclusion criteria. More RCTs of each intervention, between ECMO, prone positioning, and neuromuscular blockade would have built a stronger review and created greater generalizability. Additionally, in each study, differences in mortality rate end points was a barrier to reliably compare interventions to identify efficacy to reduce overall mortality. Such variations included a 28, 60, and 90 day mortality rate end point, which was not measured in every study. Peek et al. (2010) chose the most atypical end point of death or severe disability at six months or less. 
Conclusions drawn from this systematic review are the ACURASYS trial was underpowered, the CESAR trial displayed a decrease in mortality in the ECMO arm but did not reach statistical significance, and both the EOLIA trial and the ROSE trial were stopped for futility. Prone positioning (Guérin et al., 2013) showed the greatest decrease in mortality overall and reached statistical significance. The findings from this systematic review may assist providers and caregivers working in the ICU to choose the most appropriate, beneficial intervention to treat patients with ARDS. This comprehensive review evaluated pertinent findings regarding the use of prone positioning, neuromuscular blockade, and ECMO therapy will inform healthcare organizations to provide the right equipment and technology to implement the intervention most likely to decrease mortality. Moreover, if evidence-based interventions are selected, it may lead to fewer days spent in the ICU, and lower costs and improved quality of life for patients status post severe ARDS.

With regard to Virginia Henderson's Nursing Need Theory, it was difficult to account for all of the physiologic categories in each study; breathe normally, move and maintain desirable postures and sleep and rest. Utilization of the theorized basic needs were intended to help shape the focus of attention and discussion. Although it is important to consider these physiologic categories when treating patients with severe ARDS, as these individuals are physiologically compromised, attention was not exclusively dedicated to each of these patient needs and, thus, was not able to be incorporated into a cross study analysis table for direct comparison.

Recommendations and implications for advanced nursing practice will be discussed next 


\section{Recommendations and Implications for Advanced Nursing Practice}

Acute respiratory distress syndrome (ARDS) is a severe complication which affects thousands of patients every year and is consequently responsible for high mortality rates and increased healthcare costs. As the role of advanced practice registered nurses (APRN) continues to grow, it is imperative for practitioners to remain current and up to date on evidence-based practice and emerging new knowledge. This systematic review was able to evaluate the most recent RCTs on ARDS interventions, compare their efficiency and explore methods with inquiry in large trials. The APRN should be aware of the limited generalizability of the studies and lack of randomized control trials (RCTs) to date. Overall, this systematic review provides the APRN with relevant information to inform decision-making when caring for patients with severe ARDS.

Upon conclusion of this systematic review, some recommendations can be made. Prone positioning (Guérin et al., 2013) best demonstrates a decrease in mortality of adult patients with severe ARDS when applied early and for extended intervals of time. The use of ECMO and neuromuscular blockade cannot be completely excluded from treatment, however, further studies are required to fully understand and develop a standard of care for such interventions into regular practice. The APRN, in collaboration with the critical care team, can consider the use of these alternate interventions if prone positioning is contraindicated or not improving patient outcomes.

In considering the treatment options available to patients with severe ARDS, the APRN may consider the secondary outcomes included in this systematic review. Patients who are on a ventilator via endotracheal tube are at risk for an array of adverse events if 
mechanical ventilation settings are not carefully chosen and monitored. Examples of such adverse events consist of barotrauma, pneumothorax, ventilator-associated pneumonia (VAP), increased length of stay (LOS) in the ICU, increased LOS in the hospital, extended periods of time on the ventilator, and disturbances in serum $\mathrm{pH}$. The studies report additional secondary outcomes the APRN may consider specific to each treatment option. For example, in patients that receive ECMO, careful consideration of bleeding and exsanguination will be weighed in the decision to initiate therapy. The APRN must also consider that specific neuromuscular blockade study drugs may increase the risk of paresis, paralysis, and weakness in some patients.

The study of adults with severe ARDS and methods to decrease the notable mortality rate will continue. An APRN with the foundational knowledge provided in this systematic review will prove to be essential in the pursuit of further RCTs. Proper definition of preset protocols, standardized ventilator settings, inclusion/exclusion criteria, and use of selected severs ARDS interventions will help to create stronger trials in the future and thus, contribute to the development of evidence-based practice to support improved outcomes for adults with severe ARDS. 


\section{References}

Barmparas, G., Dhillon, N. K., Tatum, J. M., Patel, K., Thomsen, G. M., Mason, R., .. .

Ley, E. J. (2018). Extended neuromuscular blockade in acute respiratory distress syndrome does not increase mortality. Journal of Surgical Research, 231, 434-

440. doi:10.1016/j.jss.2018.06.074

Bernard, G. R., Artigas, A., Brigham, K. L., Carlet, J., Falke, K., Hudson, L., . . Spragg, R. (1994). The American-European Consensus conference on Ards. Definitions, mechanisms, relevant outcomes, and clinical TRIAL COORDINATION. American Journal of Respiratory and Critical Care Medicine, 149(3), 818-824. doi:10.1164/ajrccm.149.3.7509706

Carlucci, M., Graf, N., Simmons, J. Q. \& Corbridge, S. J. (2014). Effective management of ARDS. The Nurse Practitioner, 39(12), 35-40. doi: 10.1097/01.NPR.0000454981.96541.e6.

Combes, A., Hajage, D., Capellier, G., Demoule, A., Lavoué, S., Guervilly, C., . . . Mercat, A. (2018). Extracorporeal Membrane Oxygenation for Severe Acute Respiratory Distress Syndrome. New England Journal of Medicine,378(21), 1965-1975. doi:10.1056/nejmoa1800385

El-Haddad, H., Jang, H., Chen, W., \& Soubani, A. O. (2017). Effect of ARDS Severity 
and Etiology on Short-Term Outcomes. Respiratory Care, 62(9), 1178-1185. doi:

$10.4187 /$ respcare. 05403

Ferri, F. F. (2019). Ferris best test: a practical guide to clinical laboratory medicine and diagnostic imaging. Philadelphia, PA: Elsevier.

Gattinoni, Luciano, Tonetti, Tommaso, Quintel, Michael. "Regional Physiology of ARDS.” Critical Care, vol. 21, no. S3, 2017, doi:10.1186/s13054-017-1905-9.

Guérin, C., Reignier, J., Richard, J.-C., Beuret, P., Gacouin, A., Boulain, T., ... Ayzac, L. (2013). Prone Positioning in Severe Acute Respiratory Distress Syndrome. New England Journal of Medicine, 368(23), 2159-2168. doi: 10.1056/nejmoa1214103

Guervilly, C., Hraiech, S., Gariboldi, V., Xeridat, F., Dizier, S., Toesca, R., . . Papazian, L. (2014). Prone positioning during veno-venous extracorporeal membrane oxygenation for severe acute respiratory distress syndrome in adults. Minerva Anestesiologica, 80(3), 307-313.

Kallet, R. H., Zhuo, H., Ho, K., Lipnick, M. S., Gomez, A., \& Matthay, M. A. (2017). Lung Injury Etiology and Other Factors Influencing the Relationship Between Dead-Space Fraction and Mortality in ARDS. Respiratory Care, 62(10), 12411248. doi: $10.4187 /$ respcare. 05589 
Kallet, R. H. (2015). A Comprehensive Review of Prone Position in ARDS. Respiratory

Care, 60(11), 1660-1687. doi: 10.4187/respcare.04271

Kipping, V., Weber-Carstens, S., Lojewski, C., Feldmann, P., Rydlewski, A., Boemke, W., .. . Deja, M. (2013). Prone Position during ECMO is Safe and Improves Oxygenation. The International Journal of Artificial Organs, 36(11), 821-832. doi:10.5301/ijao.5000254

Le Gall, J. R. (1993). A new Simplified Acute Physiology Score (saps II) based on A EUROPEAN/NORTH American multicenter study. JAMA: The Journal of the American Medical Association, 270(24), 2957-2963.

doi:10.1001/jama.270.24.2957

Liberati, A., Altman, DG., Tetzlaff, J., Mulrow, C., Gotzsche, PC., Ioannidis, JPA., Clarke, M., Devereaux, PJ., Kleijnen, J., \& Moher, D. (2009). The PRISMA statement for reporting systematic reviews and meta-analyses of studies that evaluate health care interventions: Explanation and elaboration. PLos Med, 6(7). Retrieved from http://prisma-statement.org Marino, P. L. (2014). Marinos the ICU Book. Lippincott, Williams \& Wilkins. McEwen, M., \& Wills, E. M. (2019). Theoretical basis for nursing. Philadelphia: Wolters 
Kluwer Health.

Merkel, A., Massey, K., Bellamy, C., Miano, T., Fuchs, B., \&amp; Candeloro, C. (2019).

Predictors of Cisatracurium Continuous Infusion Dose in Acute Respiratory

Distress Syndrome. Journal of Pharmacy Practice, 089719001988810.

doi: $10.1177 / 0897190019888103$

Moher, D., Liberati, A., Tetzlaff, J., \&amp; Altman, D. G. (2009). Preferred reporting items for systematic reviews and meta-analyses: The prisma statement. PLoS

Medicine, 6(7). doi:10.1371/journal.pmed.1000097

Morata, Lauren, Sole, Mary; Guido-Sanz, Frank; Ogilvie, Carrie; Rich, Rebecca.

"Manual versus Automatic Prone Therapy: Impact on Patient Outcomes .”

Critical Care Medicine, vol. 46, 2018, p. 494.,

doi:10.1097/01.ccm.0000529027.54413.e5.

Moss, M., Huang, D. T., Brower, R. G., Ferguson, N. D., Ginde, A. A., Gong, M. N., .. .

Talmor, D. (2019). Early Neuromuscular Blockade in the Acute Respiratory

Distress Syndrome. New England Journal of Medicine, 380(21), 1997-2008.

doi:10.1056/nejmoa1901686

Muñoz, J., Santa-Teresa, P., Tomey, M. J., Visedo, L. C., Keough, E., Barrios, J. C., ... 
Morales, A. (2017). Extracorporeal membrane oxygenation (ECMO) in adults with acute respiratory distress syndrome (ARDS). Heart \& Lung, 46(2), 100-105. doi: 10.1016/j.hrtlng.2017.01.003

Mutkule, D. P., Rao, S., Munta, K., Venkategowda, P. M., Rao, M. V., Harde, Y. R., \& Raut, M. K. (2016). Prone position and pressure control inverse ratio ventilation in H1N1 patients with severe acute respiratory distress syndrome. Indian Journal of Critical Care Medicine, 20(1), 44-49. doi: 10.4103/0972-5229.173690

NHLBI ARDS Network. (n.d.). Retrieved December 11, 2020, from http://www.ardsnet.org/tools.shtml

Norris, Tommie L. Porths Pathophysiology: Concepts of Altered Health States. Wolters Kluwer, 2019.

Papazian, L., Forel, J., Gacouin, A., Penot-Ragon, C., Perrin, G., Loundou, A., . . Roch, A. (2010). Neuromuscular Blockers in Early Acute Respiratory Distress Syndrome. New England Journal of Medicine, 363(12), 1107-1116. doi:10.1056/nejmoa1005372

Parekh, M., Abrams, D., Brodie, D., \& Yip, N. H. (2018). Extracorporeal Membrane Oxygenation for ARDS: Optimization of Lung Protective 
Ventilation. Respiratory Care, 63(9), 1180-1188. doi: 10.4187/respcare.06262

Patel, A. R., Patel, A. R., Singh, S., Singh, S., \& Khawaja, I. (2019). Applied Uses of Extracorporeal Membrane Oxygenation Therapy. Cureus. doi: $10.7759 /$ cureus. 5163

Peek, G., Elbourne, D., Mugford, M., Tiruvoipati, R., Wilson, A., Allen, E., . . . Truesdale, A. (2010). Randomised controlled trial and parallel economic evaluation of conventional ventilatory support versus extracorporeal membrane oxygenation for severe adult respiratory failure (CESAR). Health Technology Assessment, 14(35). doi:10.3310/hta14350

Polit, D. \& Beck, C. T. (2017). Nursing research: Generating and assessing evidence for nursing practice (10th ed.). Philadelphia: Wolters Kluwer.

Raghavendran, K., \& Napolitano, L. M. (2011). Definition of ALI/ARDS. Critical care clinics, 27(3), 429-437. https://doi.org/10.1016/j.ccc.2011.05.006

Robak, O., Schellongowski, P., Bojic, A., Laczika, K., Locker, G. J., \& Staudinger, T. (2011). Short-term effects of combining upright and prone positions in patients with ARDS: a prospective randomized study. Critical Care, 15(5). doi: $10.1186 / \mathrm{cc} 10471$

Thompson, B. Taylor, et al. "Acute Respiratory Distress Syndrome.” New England 
Journal of Medicine, vol. 377, no. 6, Oct. 2017, pp. 562-572.,

doi:10.1056/nejmra1608077.

Tsai, H.-C., Chang, C.-H., Tsai, F.-C., Fan, P.-C., Juan, K.-C., Lin, C.-Y., ... Chen, Y.-C. (2015). Acute Respiratory Distress Syndrome With and Without Extracorporeal Membrane Oxygenation: A Score Matched Study. The Annals of Thoracic Surgery, 100(2), 458-464. doi: 10.1016/j.athoracsur.2015.03.092 


\section{Appendix A}

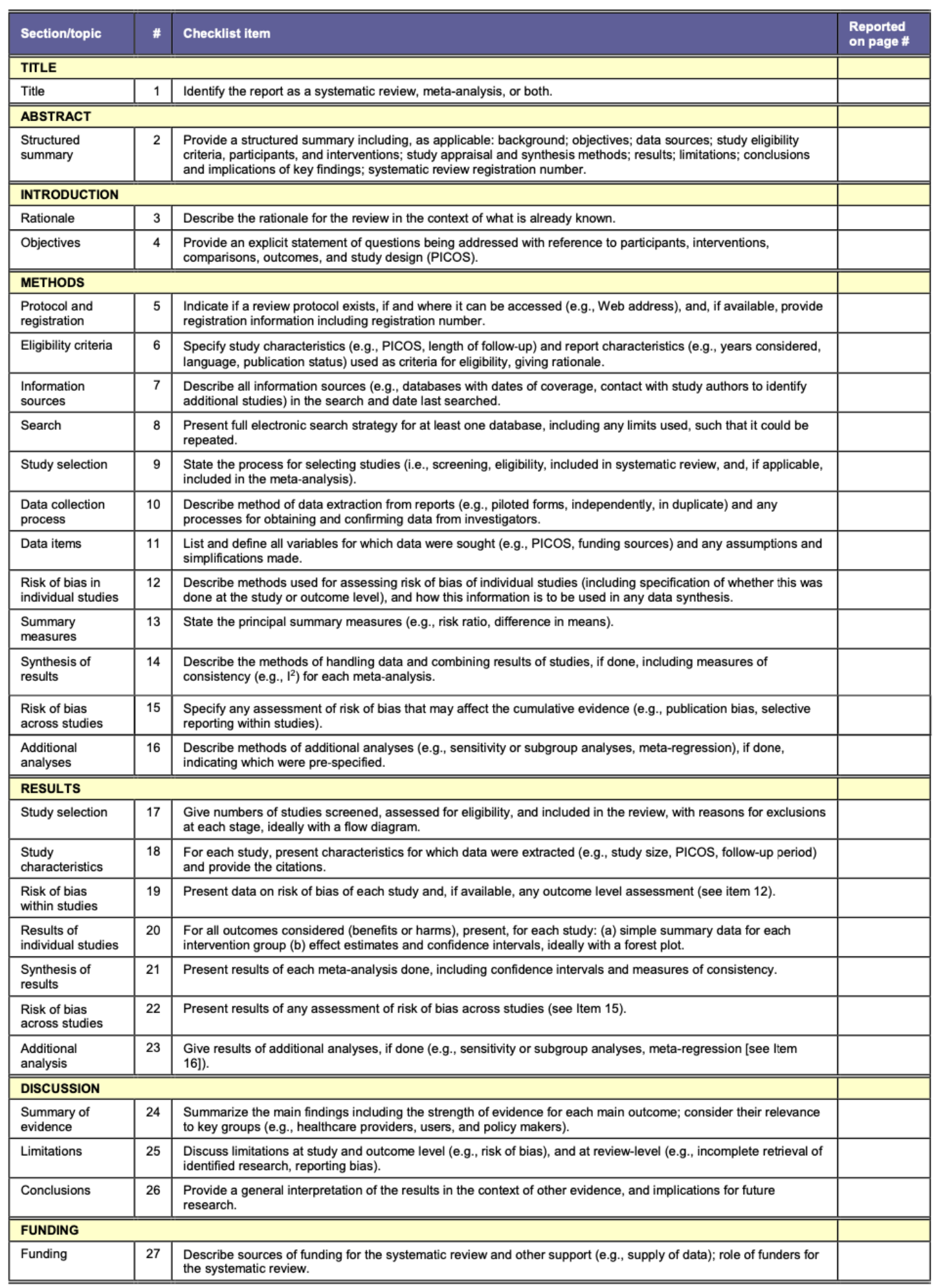

\section{Check List for Preferred Reporting Items for Systematic Reviews and Meta-Analyses (Moher et al., 2009)}




\section{Appendix B}

Table B 1

\section{Study Collection Data}

Papazian, L., Forel, J., Gacouin, A., Penot-Ragon, C., Perrin, G., Loundou, A., . . Roch, A. (2010). Neuromuscular Blockers in Early Acute Respiratory Distress Syndrome. New England Journal of Medicine, 363(12), 1107-1116. doi:10.1056/nejmoa1005372

\begin{tabular}{|c|c|c|c|c|c|}
\hline$\underline{\operatorname{Aim}}$ & Design & Site & Sample & Method & Outcome \\
\hline $\begin{array}{l}\text { Clinical outcomes } \\
\text { after } 2 \text { days of } \\
\text { therapy with }\end{array}$ & $\begin{array}{l}\text { Multicenter, } \\
\text { double-blind } \\
\text { randomized }\end{array}$ & $\begin{array}{l}20 \\
\text { ICUs } \\
\text { in }\end{array}$ & $\begin{array}{l}340 \text { adult patients } \\
\text { presenting to the ICU } \\
\text { with an onset of severe }\end{array}$ & $\begin{array}{l}\text { Randomly } \\
\text { assigned } \\
\text { patients in a }\end{array}$ & $\begin{array}{l}\text { Primary outcome was death before hospital } \\
\text { discharge or within } 90 \text { days of enrollment. }\end{array}$ \\
\hline $\begin{array}{l}\text { patients with early, } \\
\text { severe acute } \\
\text { respiratory distress }\end{array}$ & $\begin{array}{l}\text { Cisatracurium } \\
\text { besylate group }\end{array}$ & & $\begin{array}{l}178 \text { in cisatracurium } \\
\text { besylate group }\end{array}$ & $\begin{array}{l}\text { to receive } \\
\text { cisatracurium } \\
\text { besylate or a }\end{array}$ & $\begin{array}{l}\text { days } 1-28 \text { and days } 1-90 \text {, number of days } \\
\text { without organ failure between days } 1-28 \text {, } \\
\text { rate of barotrauma, rate of ICU-acquired }\end{array}$ \\
\hline syndrome (ARDS). & Placebo group & & 162 in placebo group & $\begin{array}{l}\text { placebo for } \\
48 \text { hours. }\end{array}$ & $\begin{array}{l}\text { paresis, the MRC scores on day } 28 \text { and at the } \\
\text { time of ICU discharge, and numbers of } \\
\text { ventilator-free days between days } 1-28 \text { and } \\
\text { days } 1-90 \text {. }\end{array}$ \\
\hline
\end{tabular}

Note. Severe ARDS was defined as a ratio of the partial pressure of arterial oxygen (PaO2) to the fraction of inspired oxygen (FiO2)

of less than 150, with a positive end-expiratory pressure of $5 \mathrm{~cm}$ or more of water and a tidal volume of 6 to $8 \mathrm{ml}$ per kilogram of predicted body weight. 
Table B 2

\section{Study Collection Data}

Peek, G., Elbourne, D., Mugford, M., Tiruvoipati, R., Wilson, A., Allen, E., . . . Truesdale, A. (2010). Randomised controlled trial and parallel economic evaluation of conventional ventilatory support versus extracorporeal membrane oxygenation for severe adult respiratory failure (CESAR). Health Technology Assessment, 14(35). doi:10.3310/hta14350

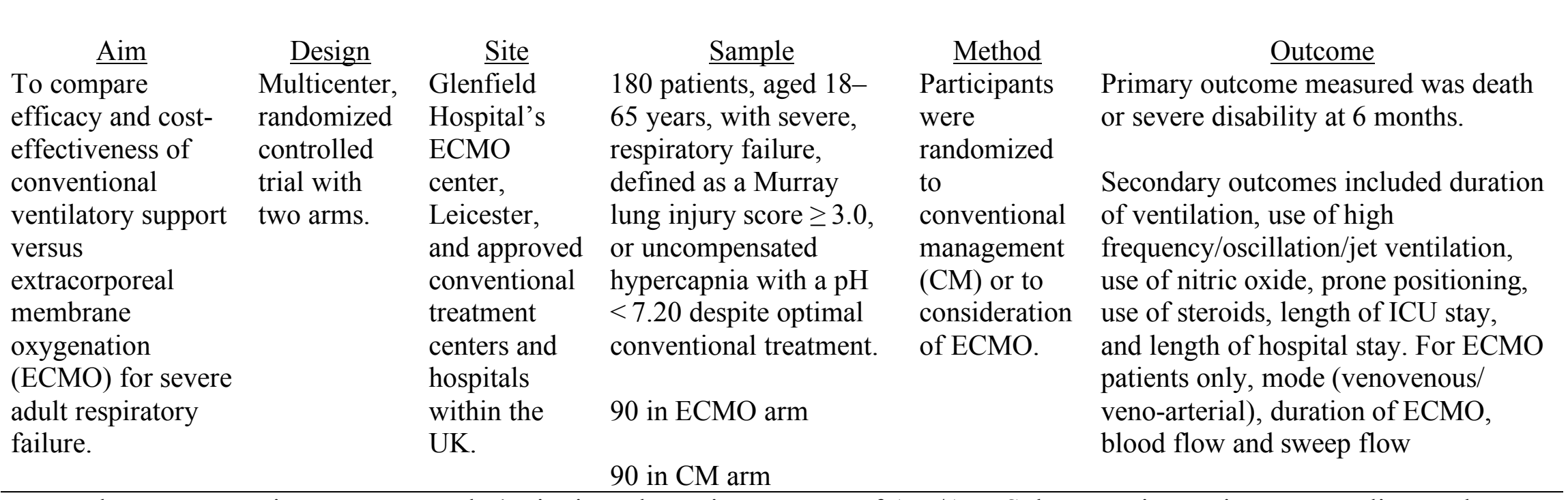

Note. The Murray scoring system regards 4 criteria to determine presence of ALI/ARDS: hypoxemia, respiratory compliance, chest

radiographic impressions, and level of PEEP. Each category is scored from 0 to 4 . A score of zero indicates no lung injury, a score of

$1-2.5$ is indicative of mild to moderate lung injury, and an ultimate score of more than 2.5 indicates the presence of ARDS. 
Table B 3

\section{Study Collection Data}

Guérin, C., Reignier, J., Richard, J.-C., Beuret, P., Gacouin, A., Boulain, T., ... Ayzac, L. (2013). Prone Positioning in Severe Acute Respiratory Distress Syndrome. New England Journal of Medicine, 368(23), 2159-2168. doi: 10.1056/nejmoa1214103

\begin{tabular}{|c|c|c|c|c|c|}
\hline \multirow{8}{*}{$\begin{array}{l}\text { Evaluation } \\
\text { of the } \\
\text { early } \\
\text { application } \\
\text { of prone } \\
\text { positioning } \\
\text { on } \\
\text { outcomes. }\end{array}$} & Design & Site & Sample & Method & Outcome \\
\hline & \multirow{7}{*}{$\begin{array}{l}\text { Multicenter, } \\
\text { prospective, } \\
\text { randomized } \\
\text { control trial }\end{array}$} & \multirow{4}{*}{$\begin{array}{l}\text { Selected } \\
\text { from } 26 \\
\text { ICU's in } \\
\text { France and } 1 \\
\text { in Spain. }\end{array}$} & \multirow{4}{*}{$\begin{array}{l}466 \text { adult patients with } \\
\text { severe acute } \\
\text { respiratory distress } \\
\text { syndrome (ARDS) and } \\
\text { intubated for less than } \\
36 \text { hours. }\end{array}$} & \multirow{5}{*}{$\begin{array}{l}\text { Random assignment of } \\
466 \text { patients with severe } \\
\text { ARDS to undergo } \\
\text { prone-positioning } \\
\text { sessions of at least } 16 \\
\text { hours or to be left in the } \\
\text { supine position. }\end{array}$} & \multirow[t]{2}{*}{$\begin{array}{l}\text { Primary end point was } 28 \text {-day } \\
\text { mortality. }\end{array}$} \\
\hline & & & & & \\
\hline & & & & & Secondary end points were 90 -day \\
\hline & & & & & $\begin{array}{l}\text { mortality, rate and time of successful } \\
\text { extubation, length of stay in the ICU. }\end{array}$ \\
\hline & & All sites & & & complications, use of noninvasive \\
\hline & & noted for & 229 in supine group & & ventilation, tracheotomy rate, number \\
\hline & & $\begin{array}{l}\text { daily practice } \\
\text { in prone } \\
\text { positioning } \\
\text { for at least } 5 \\
\text { years. }\end{array}$ & 237 in prone group & $\begin{array}{l}\text { Randomization was } \\
\text { computer-generated and } \\
\text { stratified according to } \\
\text { ICU. }\end{array}$ & $\begin{array}{l}\text { of days free from organ dysfunction, } \\
\text { ventilator settings, measurements of } \\
\text { arterial blood gases, and respiratory } \\
\text { system mechanics during the first } \\
\text { week following randomization. }\end{array}$ \\
\hline
\end{tabular}

Note. Severe ARDS was defined as a ratio of the partial pressure of arterial oxygen to the fraction of inspired oxygen (Fio2) of less

than $150 \mathrm{~mm} \mathrm{Hg}$, with an Fio2 of at least 0.6, a positive end-expiratory pressure of at least $5 \mathrm{~cm}$ of water, and a tidal volume close to 6 ml per kilogram of predicted body weight. 
Table B 4

\section{Study Collection Data}

Combes, A., Hajage, D., Capellier, G., Demoule, A., Lavoué, S., Guervilly, C., . . Mercat, A. (2018). Extracorporeal Membrane Oxygenation for Severe Acute Respiratory Distress Syndrome. New England Journal of Medicine, 378(21), $1965-1975$. doi:10.1056/nejmoa1800385

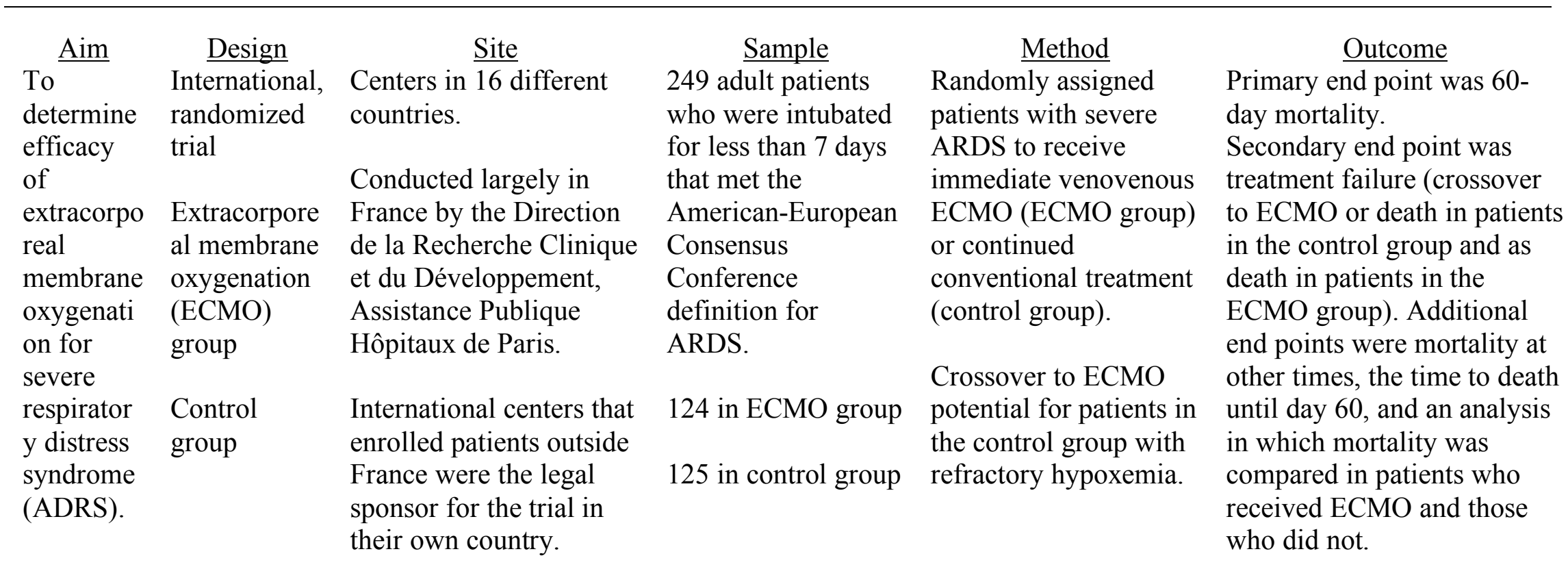

Note. Severe ARDS defined by one of three criteria: a ratio of partial pressure of arterial oxygen (Pao2) to the fraction of inspired ]

oxygen (Fio2) of less than $50 \mathrm{~mm} \mathrm{Hg}$ for more than 3 hours; a Pao:Fio2 of less than $80 \mathrm{~mm} \mathrm{Hg}$ for more than 6 hours; or an arterial blood $\mathrm{pH}$ of less than 7.25 with a partial pressure of arterial carbon dioxide of at least $60 \mathrm{~mm} \mathrm{Hg}$ for more than 6 hours. 
Table B 5

Study Collection Data

Moss, M., Huang, D. T., Brower, R. G., Ferguson, N. D., Ginde, A. A., Gong, M. N., . . Talmor, D. (2019). Early Neuromuscular Blockade in the Acute Respiratory Distress Syndrome. New England Journal of Medicine, 380(21), 1997-2008. doi:10.1056/nejmoa1901686

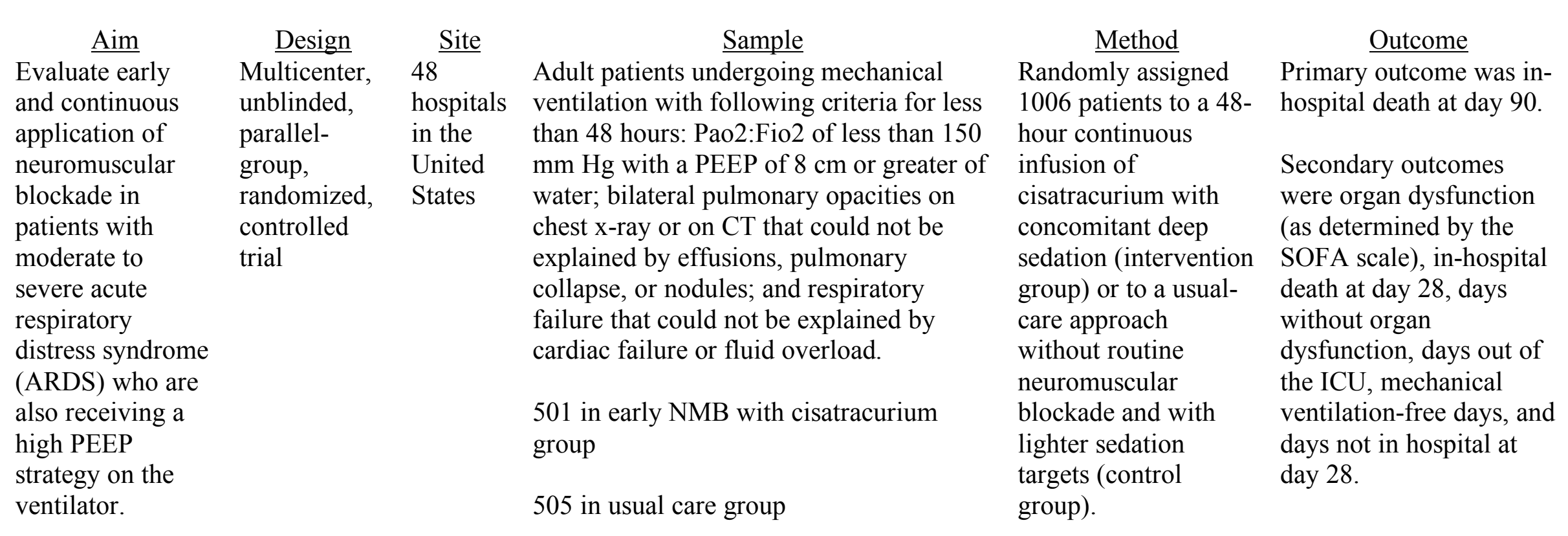

Note. Moderate to severe ARDS was defined by a ratio of the partial pressure of arterial oxygen to the fraction of inspired oxygen of $<150$

$\mathrm{mm} \mathrm{Hg}$ with a positive end-expiratory pressure $[\mathrm{PEEP}]$ of $\geq 8 \mathrm{~cm}$ of water. 


\section{Appendix C}

Table C 1

Outcome Specific Data

\begin{tabular}{|c|c|c|c|c|c|c|c|c|c|}
\hline \multicolumn{10}{|c|}{$\begin{array}{l}\text { Papazian, L., Forel, J., Gacouin, A., Penot-Ragon, C., Perrin, G., Loundou, A., . . Roch, A. (2010). Neuromuscular Blockers in } \\
\text { Early Acute Respiratory Distress Syndrome. New England Journal of Medicine, 363(12), 1107-1116. doi:10.1056/nejmoa1005372 }\end{array}$} \\
\hline & $\begin{array}{l}\text { Death at } 28 \\
\text { days no. } \\
(\%[95 \% \mathrm{CI}]\end{array}$ & $\begin{array}{l}\text { No. of } \\
\text { ventilator } \\
\text { free days } \\
\text { from day } \\
1 \text { to day } \\
28\end{array}$ & $\begin{array}{l}\text { No. of } \\
\text { ventilator } \\
\text { free days } \\
\text { from day } \\
1 \text { to day } \\
90\end{array}$ & $\begin{array}{l}\text { No. of days } \\
\text { without } \\
\text { cardiovascular } \\
\text { failure from } \\
\text { day } 1 \text { to day } \\
28\end{array}$ & $\begin{array}{l}\text { No. of days } \\
\text { without } \\
\text { coagulation } \\
\text { abnormalitie } \\
\text { s from day } 1 \\
\text { to day } 28\end{array}$ & $\begin{array}{l}\text { No. of days } \\
\text { without } \\
\text { hepatic } \\
\text { failure } \\
\text { from day } 1 \\
\text { to day } 28\end{array}$ & $\begin{array}{l}\text { No. of days } \\
\text { without } \\
\text { renal } \\
\text { failure } \\
\text { from day } 1 \\
\text { to day } 28\end{array}$ & $\begin{array}{l}\text { No. of } \\
\text { days } \\
\text { outside } \\
\text { the ICU } \\
\text { from } \\
\text { day } 1 \text { to } \\
\text { day } 28\end{array}$ & $\begin{array}{l}\text { No. of } \\
\text { days } \\
\text { outside } \\
\text { the ICU } \\
\text { from day } \\
1 \text { to day } \\
90\end{array}$ \\
\hline $\begin{array}{l}\text { isatracurium } \\
\text { iroup }\end{array}$ & $\begin{array}{l}42(23.7 \\
{[18.1-} \\
30.5])\end{array}$ & $10.6 \pm 9.7$ & $53.1 \pm 35.8$ & $18.3 \pm 9.4$ & $22.6 \pm 8.9$ & $21.3 \pm 9.6$ & $20.5 \pm 10.1$ & $6.9 \pm 8.2$ & $47.7 \pm 33.5$ \\
\hline $\begin{array}{l}\text { lacebo } \\
\text { Iroup }\end{array}$ & $\begin{array}{l}54(33.3 \\
{[26.5-} \\
40.9])\end{array}$ & $8.5 \pm 9.4$ & $44.6 \pm 37.5$ & $16.6 \pm 10.4$ & $20.5 \pm 9.9$ & $19.1 \pm 10.6$ & $18.1 \pm 11.6$ & $5.7 \pm 7.8$ & $39.5 \pm 35.6$ \\
\hline Value & 0.05 & 0.04 & 0.03 & 0.12 & 0.05 & 0.05 & 0.05 & 0.16 & 0.03 \\
\hline
\end{tabular}

Note. Confidence interval (CI). Number (no.). 
Table C 2

Outcome Specific Data

Peek, G., Elbourne, D., Mugford, M., Tiruvoipati, R., Wilson, A., Allen, E., . . . Truesdale, A. (2010). Randomised controlled trial and parallel economic evaluation of conventional ventilatory support versus extracorporeal membrane oxygenation for severe adult respiratory failure (CESAR). Health Technology Assessment, 14(35). doi:10.3310/hta14350

\begin{tabular}{|c|c|c|c|c|c|c|c|c|c|}
\hline & $\begin{array}{l}\text { Died } \leq 6 \\
\text { months or } \\
\text { died } \\
\text { before } \\
\text { discharge, } \\
\text { no }\end{array}$ & $\begin{array}{l}\text { Died } \leq 6 \\
\text { months or } \\
\text { died } \\
\text { before } \\
\text { discharge, } \\
\text { yes }\end{array}$ & $\begin{array}{l}\text { Cause of } \\
\text { death- } \\
\text { Respiratory } \\
\text { Failure }\end{array}$ & $\begin{array}{l}\text { Cause of } \\
\text { death- } \\
\text { Multi- } \\
\text { organ } \\
\text { failure }\end{array}$ & $\begin{array}{l}\text { Cause of } \\
\text { death- } \\
\text { Neurological }\end{array}$ & $\begin{array}{l}\text { Cause of } \\
\text { death- } \\
\text { Cardiovascular }\end{array}$ & $\begin{array}{l}\text { Cause of } \\
\text { death- } \\
\text { ECMO } \\
\text { related }\end{array}$ & $\begin{array}{l}\text { Median } \\
\text { days in } \\
\text { ICU }\end{array}$ & $\begin{array}{l}\text { Median } \\
\text { days in } \\
\text { hospital }\end{array}$ \\
\hline $\begin{array}{l}\text { ECMO } \\
\text { group } \\
(\mathrm{N}=90)\end{array}$ & $\mid 57$ & 33 & 8 & 14 & 4 & 1 & 1 & 24 & 35 \\
\hline $\begin{array}{l}\text { Control } \\
\text { Group } \\
(\mathrm{N}=90)\end{array}$ & 45 & 45 & 24 & 15 & 2 & 3 & 0 & 13 & 17 \\
\hline
\end{tabular}

Note. Sample size (N). Extracorporeal Membrane oxygenation (ECMO). 
Table C 3

\section{Outcome Data Collection}

Guérin, C., Reignier, J., Richard, J.-C., Beuret, P., Gacouin, A., Boulain, T., ... Ayzac, L. (2013). Prone Positioning in Severe Acute Respiratory Distress Syndrome. New England Journal of Medicine, 368(23), 2159-2168. doi: 10.1056/nejmoa1214103

\begin{tabular}{|c|c|c|c|c|c|c|c|}
\hline & $\begin{array}{l}\text { Mortality at } \\
\text { day } 28 \\
- \\
\text { no. }(\%[95 \% \mathrm{CI}]\end{array}$ & $\begin{array}{l}\text { Mortality at } \\
\text { day } 90 \\
\text { - } \\
\text { no. }(\%[95 \% \mathrm{CI}]\end{array}$ & $\begin{array}{l}\text { Successful } \\
\text { extubation at } \\
\text { day } 90- \\
\text { no. }(\%[95 \% \mathrm{CI}])\end{array}$ & $\begin{array}{l}\text { Time to } \\
\text { successful } \\
\text { extubation at } \\
\text { day } 90 \\
\text { (survivors) }\end{array}$ & $\begin{array}{l}\text { Time to } \\
\text { successful } \\
\text { extubation at } \\
\text { day } 90 \\
\text { (nonsurvivors) }\end{array}$ & $\begin{array}{l}\text { LOS ICU at } \\
\text { day } 90 \\
\text { (survivors) }\end{array}$ & $\begin{array}{l}\text { LOS ICU at } \\
\text { day } 90 \\
\text { (nonsurvivors) }\end{array}$ \\
\hline $\begin{array}{l}\text { Supine } \\
\text { group }\end{array}$ & $\begin{array}{l}75(32.8 \\
[26.4-38.6])\end{array}$ & $\begin{array}{l}94(41.0 \\
[34.6-47.4])\end{array}$ & $\begin{array}{l}145 / 223(65.0 \\
[58.7-71.3])\end{array}$ & $19 \pm 21$ & $16 \pm 11$ & $26 \pm 27$ & $18 \pm 15$ \\
\hline $\begin{array}{l}\text { Prone } \\
\text { group }\end{array}$ & $\begin{array}{l}38(16.0 \\
[11.3-20.7])\end{array}$ & $\begin{array}{l}56(23.6 \\
[18.2-29.0])\end{array}$ & $\begin{array}{l}186 / 231(80.5 \\
[75.4-85.6])\end{array}$ & $17 \pm 16$ & $18 \pm 14$ & $24 \pm 22$ & $21 \pm 20$ \\
\hline P Value & $<0.001$ & $<0.001$ & $<0.001$ & 0.87 & & 0.05 & \\
\hline
\end{tabular}




\begin{tabular}{|c|c|c|c|c|c|c|c|}
\hline & $\begin{array}{l}\text { Ventilation- } \\
\text { free days at } \\
\text { day } 28\end{array}$ & $\begin{array}{l}\text { Ventilation- } \\
\text { free days at } \\
\text { day } 90\end{array}$ & $\begin{array}{l}\text { Pneumothorax - } \\
\text { no. }(\%[95 \% \mathrm{CI}])\end{array}$ & $\begin{array}{l}\text { Noninvasive } \\
\text { ventilation at } \\
\text { day } 28 \text {-no. } \\
(\%[95 \% \mathrm{CI}])\end{array}$ & $\begin{array}{l}\text { Noninvasive } \\
\text { ventilation at } \\
\text { day } 90-\text { no. } \\
(\%[95 \% \mathrm{CI}])\end{array}$ & $\begin{array}{l}\text { Tracheostomy } \\
\text { at day } 28 \text { - } \\
\text { no./total no. } \\
(\%[95 \% \mathrm{CI}])\end{array}$ & $\begin{array}{l}\text { Tracheostomy } \\
\text { at day } 90 \text { - } \\
\text { no./total no. } \\
(\%[95 \% \mathrm{CI}])\end{array}$ \\
\hline $\begin{array}{l}\text { Supine } \\
\text { group }\end{array}$ & $10 \pm 10$ & $43 \pm 38$ & $\begin{array}{l}13(5.7[3.9- \\
7.5])\end{array}$ & $\begin{array}{l}10 / 212(4.7 \\
[1.9-7.5])\end{array}$ & $\begin{array}{l}3 / 206(1.5 \\
[0.2-3.2])\end{array}$ & $\begin{array}{l}12 / 229(5.2 \\
[2.3-8.1])\end{array}$ & $\begin{array}{l}18 / 223(8.1 \\
[4.5-11.7])\end{array}$ \\
\hline $\begin{array}{l}\text { Prone } \\
\text { group }\end{array}$ & $14 \pm 9$ & $57 \pm 34$ & $\begin{array}{l}15(6.3[4.9- \\
7.7])\end{array}$ & $\begin{array}{l}4 / 228(1.8 \\
[0.1-3.5])\end{array}$ & $\begin{array}{l}4 / 225(1.8 \\
[0.1-3.5])\end{array}$ & $\begin{array}{l}9 / 237(3.8 \\
[1.4-6.0])\end{array}$ & $\begin{array}{l}15 / 235(6.4 \\
[3.3-9.5])\end{array}$ \\
\hline P Value & $<0.001$ & $<0.001$ & 0.85 & 0.11 & 1.00 & 0.37 & 0.59 \\
\hline
\end{tabular}

Note. Length of Stay (LOS). Confidence Interval (CI). Number (no.). 
Table C 4

\section{Outcome Data Collection}

Combes, A., Hajage, D., Capellier, G., Demoule, A., Lavoué, S., Guervilly, C., . . Mercat, A. (2018). Extracorporeal Membrane Oxygenation for Severe Acute Respiratory Distress Syndrome. New England Journal of Medicine, 378(21), $1965-1975$. doi:10.1056/nejmoa1800385

\begin{tabular}{|c|c|c|c|c|c|c|c|c|c|}
\hline & $\begin{array}{l}\text { Mortality } \\
\text { at } 60 \\
\text { days- }- \\
\text { no. }(\%)\end{array}$ & $\begin{array}{l}\text { Treatment } \\
\text { failure at } \\
60 \text { days - } \\
\text { no. }(\%)\end{array}$ & $\begin{array}{l}\text { Mortality } \\
\text { at } 90 \text { days } \\
\text { — no. }(\%)\end{array}$ & $\begin{array}{l}\text { Median } \\
\text { length of } \\
\text { stay in } \\
\text { ICU }\end{array}$ & $\begin{array}{l}\text { Median } \\
\text { length of } \\
\text { stay in } \\
\text { hospital }\end{array}$ & $\begin{array}{l}\text { Recruitment } \\
\text { maneuvers - } \\
\text { no. }(\%)\end{array}$ & $\begin{array}{l}\text { Inhaled } \\
\text { nitric oxide } \\
\text { or } \\
\text { prostacyclin } \\
\text { - no. }(\%)\end{array}$ & $\begin{array}{l}\text { Glucocorticoids } \\
\text { - no. }(\%)\end{array}$ & $\begin{array}{l}\text { Prone } \\
\text { position } \\
\text {-no. (\%) }\end{array}$ \\
\hline $\begin{array}{l}\text { ECMO } \\
\text { Group } \\
(\mathrm{N}=124)\end{array}$ & $44(35)$ & $44(35)$ & $46(37)$ & $\begin{array}{l}23(13- \\
34)\end{array}$ & $36(19-48)$ & $27(22)$ & $75(60)$ & $80(65)$ & $82(66)$ \\
\hline $\begin{array}{l}\text { Control } \\
\text { Group } \\
(\mathrm{N}=125)\end{array}$ & $57(46)$ & $72(58)$ & $59(47)$ & $18(8-33)$ & $18(5-43)$ & $54(43)$ & $104(83)$ & $82(66)$ & $113(90)$ \\
\hline P Value & 0.09 & $<0.001$ & & & & & & & \\
\hline
\end{tabular}

Note. Sample size (N). Number (no.). 


\section{Table C 5}

Outcome Specific Data

Moss, M., Huang, D. T., Brower, R. G., Ferguson, N. D., Ginde, A. A., Gong, M. N., . . Talmor, D. (2019). Early Neuromuscular Blockade in the Acute Respiratory Distress Syndrome. New England Journal of Medicine, 380(21), 1997-2008.

doi:10.1056/nejmoa1901686

\begin{tabular}{|c|c|c|c|c|c|c|c|c|}
\hline $\begin{array}{l}\text { In- } \\
\text { hospital } \\
\text { death by } \\
\text { day } 90- \\
\text { no. }(\%)\end{array}$ & $\begin{array}{l}\text { In- } \\
\text { hospital } \\
\text { death } \\
\text { by day } \\
28-\text { no. } \\
(\%)\end{array}$ & $\begin{array}{l}\text { Days free } \\
\text { of } \\
\text { ventilation }\end{array}$ & $\begin{array}{l}\text { Serious } \\
\text { adverse } \\
\text { events- } \\
\text { no. }\end{array}$ & $\begin{array}{l}\text { Serious } \\
\text { cardiovascular } \\
\text { adverse } \\
\text { events- no. }\end{array}$ & $\begin{array}{l}\text { Atrial } \\
\text { fibrillation } \\
\text { or SVT } \\
\text { during } \\
\text { ICU stay- } \\
\text { no. }(\%)\end{array}$ & $\begin{array}{l}\text { Barotrauma- } \\
\text { no. }(\%)\end{array}$ & $\begin{array}{l}\text { Pneumothorax } \\
\text { on days } 0 \text { to } \\
\text { 2- no. }(\%)\end{array}$ & $\begin{array}{l}\text { Pneumothorax } \\
\text { on days } 0 \text { to } \\
7 \text { - no. }(\%)\end{array}$ \\
\hline
\end{tabular}

\begin{tabular}{|c|c|c|c|c|c|c|c|c|c|}
\hline $\begin{array}{l}\text { Intervention } \\
\text { Group }\end{array}$ & $\begin{array}{l}213 \\
(42.5 \pm 2.2)\end{array}$ & $\begin{array}{l}184 \\
(36.7)\end{array}$ & $9.6 \pm 10.4$ & 35 & 14 & $101(20.2)$ & $20(4.0)$ & $8(1.6)$ & $14(2.8)$ \\
\hline $\begin{array}{l}\text { Control } \\
\text { Group }\end{array}$ & $\begin{array}{l}216 \\
(42.8 \pm 2.2)\end{array}$ & $\begin{array}{l}187 \\
(37.0)\end{array}$ & $9.9 \pm 10.9$ & 22 & 4 & 99 (19.6) & $32(6.3)$ & $10(2.0)$ & $25(5.0)$ \\
\hline P Value & 0.93 & & & 0.09 & 0.02 & 0.88 & 0.12 & 0.81 & 0.10 \\
\hline
\end{tabular}

Note. Supraventricular Tachycardia (SVT). Number (no.). 


\section{Appendix D 1}

\begin{tabular}{|c|c|c|c|}
\hline $\begin{array}{l}\text { Papazian, L., Forel, J., Gacouin, A., Penot-Ragon, C., Perrin, G } \\
\text { (2010). Neuromuscular Blockers in Early Acute Respiratory Di } \\
\text { England Journal of Medicine, 363(12), 1107-1116. doi:10.1056 }\end{array}$ & /nejm & $\begin{array}{l}\text { A., . } \\
\text { rome. } \\
5372\end{array}$ & \\
\hline Section A: Are the results of the trial valid? & Yes & $\begin{array}{l}\text { Can’t } \\
\text { Tell }\end{array}$ & No \\
\hline 1. Did the trial address a clearly focused issue & $\mathbf{X}$ & & \\
\hline $\begin{array}{l}\text { 2. Was the assignment of patients to treatments } \\
\text { randomized? }\end{array}$ & $\mathbf{X}$ & & \\
\hline $\begin{array}{l}\text { 3. Were all of the patients who entered the trial } \\
\text { properly accounted for? }\end{array}$ & $\mathbf{X}$ & & \\
\hline $\begin{array}{l}\text { 4. Were patients, healthcare workers and study } \\
\text { personnel 'blind' to treatment? }\end{array}$ & $\mathbf{X}$ & & \\
\hline 5. Were the groups similar at the start of the trial? & $\mathbf{X}$ & & \\
\hline $\begin{array}{l}\text { 6. Aside from the experimental intervention, were the } \\
\text { groups treated equally? With one exception in the } \\
\text { conventional arm. One patient was put on an experimental } \\
\text { form of lung support, known as Novalung, which violated the } \\
\text { protocol. }\end{array}$ & $\mathbf{X}$ & & \\
\hline Section B: What are the results? & & & \\
\hline $\begin{array}{l}\text { 7. How large was the treatment effect? The 90-day } \\
\text { mortality in the cisatracurium group was } 31.6 \% \text { (56 patients) } \\
\text { and } 40.7 \% \text { (66 patients) in the placebo group. }\end{array}$ & & & \\
\hline $\begin{array}{l}\text { 8. How precise was the estimate of treatment effect? The } \\
\text { cisatracurium group had an absolute reduction of } 9 \% \text { in } \\
\text { mortality at day } 90 \text { or discharge. The sample size of this study } \\
\text { was based on comparisons to two earlier groups. Since the } \\
\text { mortality of the placebo group in this study was lower than } \\
\text { that of the control group in earlier studies, this study was } \\
\text { underpowered. } 855 \text { patients would have been required to } \\
\text { produce an } 80 \% \text { statistical power. }\end{array}$ & & & \\
\hline Section C: Will the results help locally? & Yes & $\begin{array}{l}\text { Can't } \\
\text { Tell }\end{array}$ & No \\
\hline $\begin{array}{l}\text { 9. Can the results be applied to the local population, or } \\
\text { in your context? }\end{array}$ & $\mathbf{X}$ & & \\
\hline $\begin{array}{l}\text { 10. Were all the clinically important outcomes } \\
\text { considered? }\end{array}$ & $\mathbf{X}$ & & \\
\hline 11. Are the benefits worth the harms and costs? & $\mathbf{X}$ & & \\
\hline
\end{tabular}




\section{Appendix D 2}

Peek, G., Elbourne, D., Mugford, M., Tiruvoipati, R., Wilson, A., Allen, E., ... Truesdale, A. (2010). Randomised controlled trial and parallel economic evaluation of conventional ventilatory support versus extracorporeal membrane oxygenation for severe adult respiratory failure (CESAR). Health Technology Assessment, 14(35). doi:10.3310/hta14350

\begin{tabular}{|c|c|c|c|}
\hline Section A: Are the results of the trial valid? & Yes & $\begin{array}{l}\text { Can't } \\
\text { Tell }\end{array}$ & No \\
\hline 1. Did the trial address a clearly focused issue & $\mathbf{X}$ & & \\
\hline $\begin{array}{l}\text { 2. Was the assignment of patients to treatments } \\
\text { randomized? }\end{array}$ & $\mathbf{X}$ & & \\
\hline $\begin{array}{l}\text { 3. Were all of the patients who entered the trial } \\
\text { properly accounted for? Three patients in the conventional } \\
\text { arm declined permission for follow up. }\end{array}$ & & & $\mathbf{X}$ \\
\hline $\begin{array}{l}\text { 4. Were patients, healthcare workers and study } \\
\text { personnel 'blind' to treatment? Non-blinded to clinicians. } \\
\text { Blinded to researchers at six-month follow up. }\end{array}$ & & & $\mathbf{X}$ \\
\hline 5. Were the groups similar at the start of the trial? & $\mathbf{X}$ & & \\
\hline $\begin{array}{l}\text { 6. Aside from the experimental intervention, were the } \\
\text { groups treated equally? }\end{array}$ & $\mathbf{X}$ & & \\
\hline \multicolumn{4}{|l|}{ Section B: What are the results? } \\
\hline $\begin{array}{l}\text { 7. How large was the treatment effect? Mortality in the } \\
\text { ECMO arm was lower than the conventional arm, however it } \\
\text { did not reach statistical significance. }\end{array}$ & & & \\
\hline $\begin{array}{l}\text { 8. How precise was the estimate of treatment effect? } \\
\text { Original power calculations were based on anticipated } 70 \% \\
\text { mortality prediction in the control group. The researchers } \\
\text { considered a } 10 \% \text { chance of severe disability in both arms } \\
\text { and determined } 240 \text { total patients were required. Sample size } \\
\text { review conducted in } 2003 \text { revealed only } 60 \% \text { of target size } \\
\text { was obtained. It was agreed that a lower sample size of } 180 \\
\text { patients would be enough to detect a reduction by } 1 / 3 \text {. }\end{array}$ & & & \\
\hline Section C: Will the results help locally? & Yes & $\begin{array}{l}\text { Can't } \\
\text { Tell }\end{array}$ & No \\
\hline $\begin{array}{l}\text { 9. Can the results be applied to the local population, or } \\
\text { in your context? }\end{array}$ & $\mathbf{X}$ & & \\
\hline $\begin{array}{l}\text { 10. Were all the clinically important outcomes } \\
\text { considered? }\end{array}$ & $\mathbf{X}$ & & \\
\hline 11. Are the benefits worth the harms and costs? & $\mathbf{X}$ & & \\
\hline
\end{tabular}




\section{Appendix D 3}

Guérin, C., Reignier, J., Richard, J.-C., Beuret, P., Gacouin, A., Boulain, T., ... Ayzac, L. (2013). Prone Positioning in Severe Acute Respiratory Distress Syndrome. New England Journal of Medicine, 368(23), 2159-2168. doi: 10.1056/nejmoa1214103

\begin{tabular}{|c|c|c|c|}
\hline Section A: Are the results of the trial valid? & Yes & $\begin{array}{l}\text { Can’t } \\
\text { Tell }\end{array}$ & No \\
\hline 1. Did the trial address a clearly focused issue & $\mathbf{X}$ & & \\
\hline $\begin{array}{l}\text { 2. Was the assignment of patients to treatments } \\
\text { randomized? }\end{array}$ & $\mathbf{X}$ & & \\
\hline $\begin{array}{l}\text { 3. Were all of the patients who entered the trial } \\
\text { properly accounted for? }\end{array}$ & $\mathbf{X}$ & & \\
\hline $\begin{array}{l}\text { 4. Were patients, healthcare workers and study } \\
\text { personnel 'blind' to treatment? Blinding of outcome } \\
\text { assessors. }\end{array}$ & & & $\mathbf{X}$ \\
\hline $\begin{array}{l}\text { 5. Were the groups similar at the start of the trial? One } \\
\text { exception is that the SOFA score was uneven, with the mean } \\
\text { supine group measuring } 10.4 \pm 3.4 \text { and } 9.6 \pm 3.2 \text { in the prone } \\
\text { group. }\end{array}$ & $\mathbf{X}$ & & \\
\hline $\begin{array}{l}\text { 6. Aside from the experimental intervention, were the } \\
\text { groups treated equally? Two interventions used were } \\
\text { unevenly distributed. Use of vasopressors (supine } 83 \% \text { and } \\
\text { prone } 72.6 \% \text { ) and neuromuscular blockers (supine } 82.3 \% \text { and } \\
\text { prone } 91 \% \text { ). }\end{array}$ & & & $\mathbf{X}$ \\
\hline \multicolumn{4}{|l|}{ Section B: What are the results? } \\
\hline \multicolumn{4}{|l|}{$\begin{array}{l}\text { 7. How large was the treatment effect? The prone group } \\
\text { had a } 51 \% \text { relative reduction and } 17 \% \text { absolute reduction in } \\
\text { 28-day mortality compared to the supine group. }\end{array}$} \\
\hline \multicolumn{4}{|l|}{$\begin{array}{l}\text { 8. How precise was the estimate of treatment effect? An } \\
\text { estimated sample of } 456 \text { patients would generate a } 90 \% \\
\text { power to detect an absolute reduction of } 15 \text { percentage points } \\
\text { with prone positioning. }\end{array}$} \\
\hline Section C: Will the results help locally? & Yes & $\begin{array}{l}\text { Can't } \\
\text { Tell }\end{array}$ & No \\
\hline $\begin{array}{l}\text { 9. Can the results be applied to the local population, or } \\
\text { in your context? }\end{array}$ & $\mathbf{X}$ & & \\
\hline $\begin{array}{l}\text { 10. Were all the clinically important outcomes } \\
\text { considered? }\end{array}$ & $\mathbf{X}$ & & \\
\hline 11. Are the benefits worth the harms and costs? & $\mathbf{X}$ & & \\
\hline
\end{tabular}




\section{Appendix D 4}

Combes, A., Hajage, D., Capellier, G., Demoule, A., Lavoué, S., Guervilly, C., .. . Mercat, A. (2018). Extracorporeal Membrane Oxygenation for Severe Acute Respiratory Distress Syndrome. New England Journal of Medicine, 378(21), 1965-1975. doi:10.1056/nejmoa1800385

\begin{tabular}{|c|c|c|c|}
\hline Section A: Are the results of the trial valid? & Yes & $\begin{array}{l}\text { Can't } \\
\text { Tell }\end{array}$ & No \\
\hline 1. Did the trial address a clearly focused issue & $\mathbf{X}$ & & \\
\hline $\begin{array}{l}\text { 2. Was the assignment of patients to treatments } \\
\text { randomized? }\end{array}$ & $\mathbf{X}$ & & \\
\hline $\begin{array}{l}\text { 3. Were all of the patients who entered the trial } \\
\text { properly accounted for? }\end{array}$ & $\mathbf{X}$ & & \\
\hline $\begin{array}{l}\text { 4. Were patients, healthcare workers and study } \\
\text { personnel 'blind' to treatment? Medical and nursing } \\
\text { staff not blinded, participants not blinded. Research staff } \\
\text { members were blinded }\end{array}$ & & & $\mathbf{X}$ \\
\hline 5. Were the groups similar at the start of the trial? & $\mathbf{X}$ & & \\
\hline $\begin{array}{l}\text { 6. Aside from the experimental intervention, were the } \\
\text { groups treated equally? Not all of the patients who } \\
\text { received ECMO received the therapy in an ECMO center. }\end{array}$ & & & $\mathbf{X}$ \\
\hline \multicolumn{4}{|l|}{ Section B: What are the results? } \\
\hline \multicolumn{4}{|l|}{$\begin{array}{l}\text { 7. How large was the treatment effect? At day } 60 \text {, } \\
\text { mortality in the ECMO group was } 35 \% \text { compared to } 46 \% \\
\text { in the control group. } 60 \text {-day mortality was not } \\
\text { significantly lower in the ECMO group. }\end{array}$} \\
\hline \multicolumn{4}{|l|}{$\begin{array}{l}\text { 8. How precise was the estimate of treatment effect? At } \\
\text { an alpha level of } 5 \% \text { and with group-sequential analysis } \\
\text { after randomization of } 60 \text { patients, the maximum sample } \\
\text { would need to be } 331 \text { to have an } 80 \% \text { power. At the fourth } \\
\text { planned sequential interim analysis, the trial was stopped } \\
\text { in accordance with prespecified rules, leaving } 249 \\
\text { patients included in the trial. }\end{array}$} \\
\hline Section C: Will the results help locally? & Yes & $\begin{array}{l}\text { Can’t } \\
\text { Tell }\end{array}$ & No \\
\hline $\begin{array}{l}\text { 9. Can the results be applied to the local population, or } \\
\text { in your context? }\end{array}$ & $\mathbf{X}$ & & \\
\hline $\begin{array}{l}\text { 10. Were all the clinically important outcomes } \\
\text { considered? }\end{array}$ & $\mathbf{X}$ & & \\
\hline 11. Are the benefits worth the harms and costs? & & & $\mathbf{X}$ \\
\hline
\end{tabular}




\section{Appendix D 5}

\begin{tabular}{|c|c|c|c|}
\hline \multicolumn{4}{|c|}{$\begin{array}{l}\text { Moss, M., Huang, D. T., Brower, R. G., Ferguson, N. D., Ginde, A. } \\
\text { Talmor, D. (2019). Early Neuromuscular Blockade in the Acute Res } \\
\text { Syndrome. New England Journal of Medicine, } 380(21) \text {, 1997-2008. } \\
\text { doi:10.1056/nejmoa1901686 }\end{array}$} \\
\hline Section A: Are the results of the trial valid? & Yes & $\begin{array}{l}\text { Can't } \\
\text { Tell }\end{array}$ & No \\
\hline 1. Did the trial address a clearly focused issue & $\mathbf{X}$ & & \\
\hline $\begin{array}{l}\text { 2. Was the assignment of patients to treatments } \\
\text { randomized? }\end{array}$ & $\mathbf{X}$ & & \\
\hline $\begin{array}{l}\text { 3. Were all of the patients who entered the trial } \\
\text { properly accounted for? }\end{array}$ & $\mathbf{X}$ & & \\
\hline $\begin{array}{l}\text { 4. Were patients, healthcare workers and study } \\
\text { personnel 'blind' to treatment? }\end{array}$ & & & $\mathbf{X}$ \\
\hline 5. Were the groups similar at the start of the trial? & $\mathbf{X}$ & & \\
\hline $\begin{array}{l}\text { 6. Aside from the experimental intervention, were the } \\
\text { groups treated equally? }\end{array}$ & $\mathbf{X}$ & & \\
\hline \multicolumn{4}{|l|}{ Section B: What are the results? } \\
\hline $\begin{array}{l}\text { 7. How large was the treatment effect? At day } 90 \text {, any } \\
\text { cause of in-hospital death occurred in } 213 \text { patients } \\
(42.5 \%) \text { in the cisatracurium group and } 216 \text { patients } \\
(42.8 \%) \text { in the control group }(P=0.93)\end{array}$ & & & \\
\hline $\begin{array}{l}\text { 8. How precise was the estimate of treatment effect? At } \\
\text { a two-sides alpha level of } 0.05 \text {, it was calculated that } \\
1408 \text { patients would need to be studied in order for the } \\
\text { trial to have } 90 \% \text { statistical power. } 1006 \text { patients were } \\
\text { included, however, by the second interim analysis, the } \\
\text { trial was stopped for futility. }\end{array}$ & & & \\
\hline Section C: Will the results help locally? & Yes & $\begin{array}{l}\text { Can’t } \\
\text { Tell }\end{array}$ & No \\
\hline $\begin{array}{l}\text { 9. Can the results be applied to the local population, or } \\
\text { in your context? }\end{array}$ & $\mathbf{X}$ & & \\
\hline $\begin{array}{l}\text { 10. Were all the clinically important outcomes } \\
\text { considered? }\end{array}$ & $\mathbf{X}$ & & \\
\hline 11. Are the benefits worth the harms and costs? & & $\mathbf{X}$ & \\
\hline
\end{tabular}




\section{Appendix E}

\section{Cross Study Analysis}

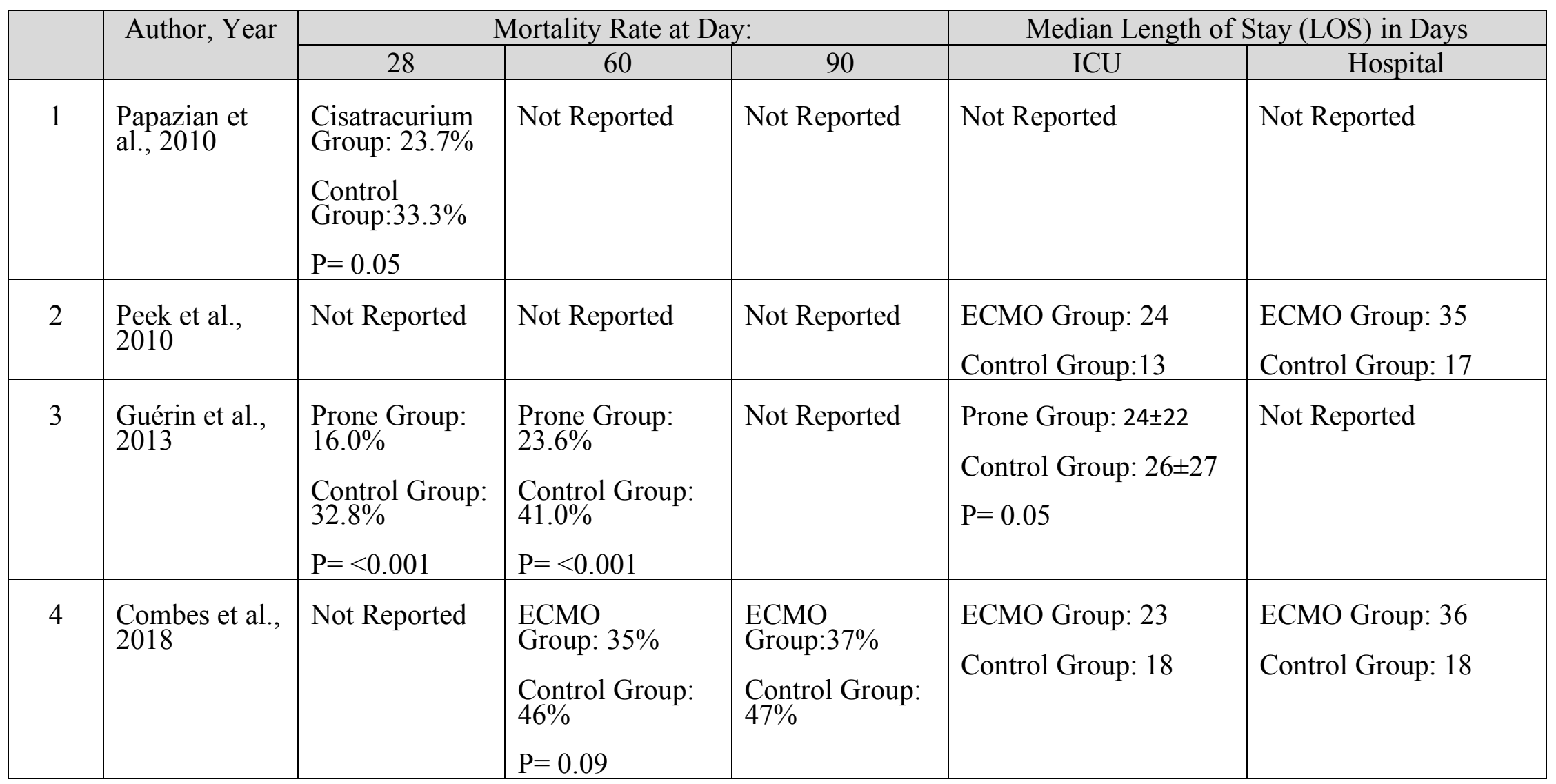




\begin{tabular}{|c|l|l|l|l|l|l|}
\hline 5 & $\begin{array}{l}\text { Moss et al., } \\
2019\end{array}$ & $\begin{array}{l}\text { Cisatracurium } \\
\text { Group: 36.7\% } \\
\text { Control Group: } \\
37.0 \%\end{array}$ & Not Reported & $\begin{array}{l}\text { Cisatracurium } \\
\text { Group: 213 } \\
(42.5 \pm 2.2)\end{array}$ & Not Reported & Not Reported \\
& & & $\begin{array}{l}\text { Control Group: } \\
216(42.8 \pm 2.2) \\
\mathrm{P}=0.93\end{array}$ & & \\
\hline
\end{tabular}


